Portland State University

PDXScholar

Fall 11-30-2017

\title{
Multilingualism and Multiculturalism: Opinions from Spanish-Speaking English Learners from Mexico, Central America, and South America
}

Cailey Catherine Moe

Portland State University

Follow this and additional works at: https://pdxscholar.library.pdx.edu/open_access_etds

Part of the Applied Linguistics Commons, and the First and Second Language Acquisition Commons Let us know how access to this document benefits you.

\section{Recommended Citation}

Moe, Cailey Catherine, "Multilingualism and Multiculturalism: Opinions from Spanish-Speaking English Learners from Mexico, Central America, and South America" (2017). Dissertations and Theses. Paper 4059.

https://doi.org/10.15760/etd.5943

This Thesis is brought to you for free and open access. It has been accepted for inclusion in Dissertations and Theses by an authorized administrator of PDXScholar. Please contact us if we can make this document more accessible: pdxscholar@pdx.edu. 
Multilingualism and Multiculturalism:

Opinions from Spanish-Speaking English Learners from

Mexico, Central America, and South America

\author{
by \\ Cailey Catherine Moe
}

A thesis submitted in partial fulfillment of the requirements for the degree of

\author{
Master of Arts \\ in \\ Teaching English to Speakers of Other Languages
}

Thesis Committee:

John Hellermann, Chair

Kathy Harris

Jenny Mittelstaedt

Portland State University

2017 


\begin{abstract}
Within the population of adult English-language learners in the United States, the largest portion is comprised of Spanish speakers from Mexico and Central and South America. At the same time, Spanish is the second-most commonly spoken language in the U.S., and an increasing presence in U.S. media and culture. This puts English learners from this demographic in a unique position with respect to language and culture acquisition and the experience of working towards their goals within U.S. society at large.

The purpose of this study is to explore motivations and beliefs about language and culture held by a small number English-language learners belonging to this huge, diverse community. Drawing on theory from the fields of second language acquisition and sociolinguistics, a survey eliciting opinions about cultural affiliation and language standards was created and versions in either English or Spanish were distributed to volunteers from this population living in Oregon. Fiftytwo surveys were returned. The responses to the surveys were then compared with one another to examine any connections between participant beliefs about language value, cultural affiliation, and learning strategy preferences. Statistical comparisons were also carried out to determine whether certain orientations correlated with one another.

Analysis of the survey responses showed that while affiliation to United States culture was variable, all participants maintained at least a moderate feeling of affiliation to their home countries, despite twenty-seven, or just over half, of them having lived in the U.S. for over ten years. However, all but one of the participants
\end{abstract}


were also interested in learning about U.S. culture and thirty-nine believed in the possibility of being part of more than one culture at a time. Participants were more likely to prefer collaborative strategies for learning about culture, but for learning language they preferred individual strategies, and had a general low estimation of the utility of non-standard forms of language, including non-standard English and Spanglish. A moderate negative correlation (Spearman $\rho=.521$ ) that was statistically significant $(\mathrm{p}=.001)$ was found between the degree to which participants had a multicultural affiliation and their beliefs about the importance of knowing non-standard forms of English.

While the participating sample is too small and opportunistic for the findings to be generalizable, from the results of the surveys it can be concluded that: multicultural affiliation is something that can be (and is) experienced to varying degrees by some language learners in this population sample; individual learning strategies seem preferred for learning language; and non-standard English is not considered as valuable as standard English. Additionally, a negative correlation between multicultural affiliation and the perceived importance of knowing nonstandard English is suggested. These findings may have implications for language instructors and others who wish to investigate the motivations, priorities, and language beliefs of adult English students from this particular demographic. 


\section{Acknowledgments}

I would like to express my sincere appreciation for my thesis committee: Advisor John Hellermann, Kathy Harris, and Jenny Mittelstaedt.

I am deeply grateful to the ESOL department chairs and the many teachers who invited me to their classes and helped me find research participants, and demonstrated kindness and collaboration that I hope to emulate. Extra thanks go to Teressa Farquhar and Heidi Saleska for facilitating the opportunity for their students to complete surveys, and to Donna Mae Fiore and Kiersta Fricke-Gostnell, for all of the above and beyond, and for hosting me at RCC multiple times. Even more thanks go to Becky George and Evalyn Hansen for their endless encouragement, assistance, and support.

I am also indebted to my friends and colleagues who gave invaluable help with the Spanish-language versions of the research materials: Renee Harger and Ricardo Varela, Roberto Garcia, Esther Kukielka, and Juliana Sarmiento.

My profound gratitude goes also to all the English learners who participated in this research project.

Finally, it is impossible to overstate the importance of the assistance and support given to me by my parents, Tom and Vicki Moe, and my husband, Cole Robinson. Thank you. 


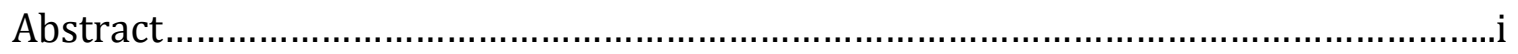

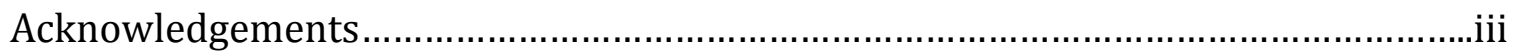

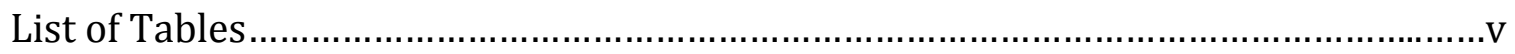

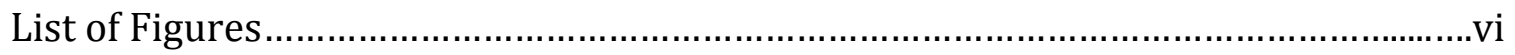

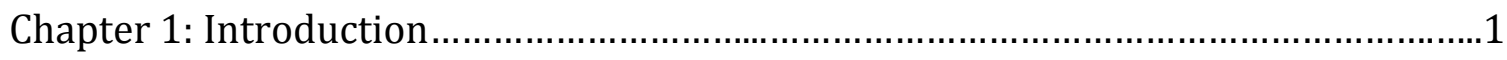

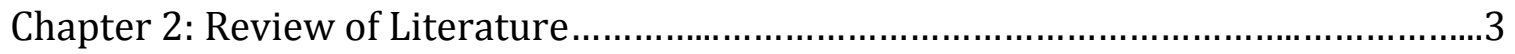

Chapter 3: Research Questions and Methodology ...........................................11

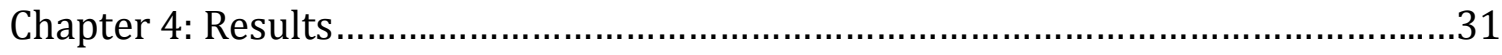

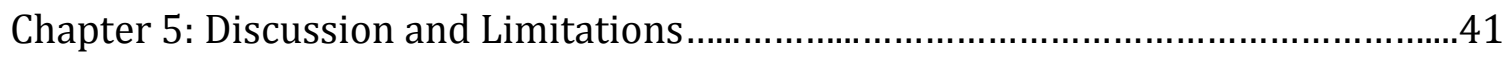

Chapter 6: Implications and Conclusion........................................................ 51

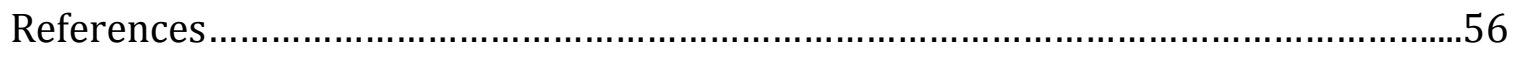

Appendices

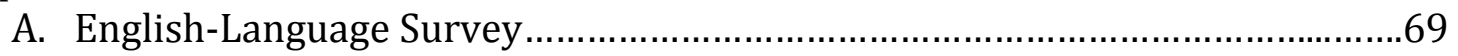

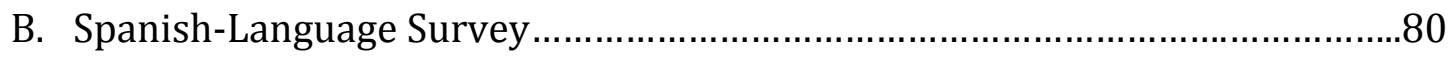

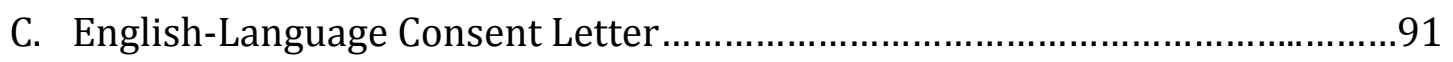

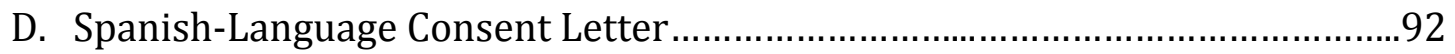




\section{List of Tables}

Table 1. Reasons for Learning English................................................................32 


\section{List of Figures}

Figure 1. Citizenship of Participants............................................................... 19

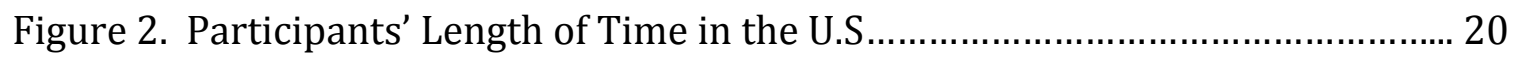

Figure 3. Individual Cultural Affiliation Scores for Home Country and the U.S. .......33

Figure 4. Preferred Learning Strategies: U.S. Culture ..........................................

Figure 5. Preferred Learning Strategies: Standard English..................................35

Figure 6. Preferred Learning Strategies: Non-Standard English............................36

Figure 7. Language Use Frequency: Standard English.........................................

Figure 8. Language Use Frequency: Spanglish/mix of English and Spanish.............37

Figure 9. Language Variety Applicability: Non-Standard English and Spanglish/Mix of English and Spanish...................................................39 


\section{Chapter 1: Introduction}

In 2010, 40 million foreign-born United States residents comprised $12.9 \%$ of the total population (United States Census Bureau, ca. 2010). One in five Americans is foreign-born or has a parent who is foreign-born (Bedolla, 2006, p. 51). Of children under the age of eighteen, one in four have at least one foreign-born parent. (United States Census Bureau, ca. 2010). As the population of foreign-born residents grows, the number of people seeking English-language instruction continues to grow.

Of the 40 million aforementioned foreign-born U.S. residents, $37 \%$ of these are people from Mexico (29\%) or Central America (8\%) (United States Census Bureau, ca. 2010). Speakers of "Spanish or Spanish Creole" comprise $62 \%$ of the population of residents over 5 years old who spoke a language other than English in the home (Ryan, 2013, p. 3). The size of this population and the fact that Spanish is the second-most common language in the U.S. creates the potential for particular experiences of learning English and adapting to life in the U.S.

Within the TESOL community in the United States, there is much discussion about the experiences of immigrants learning a language in a new place. It is true that an understanding of larger social context is instrumental in our ability to serve language learners (McKay \& Wong, 2000, p.3). However, understanding how learners encounter, interact with, and adapt to larger social contexts is also important. This study attempts to explore a facet of the linguistic and cultural adjustments experienced by the most populous group of immigrant Englishlanguage learners: Spanish-speakers from Mexico and Central and South America. 


\section{On Terminology}

Though immigrants from Mexico, Central America, and South America have distinct histories, cultures and linguistic characteristics, in the U.S. they are often referred to collectively as Hispanics or Latinos/as (Amaya, 2013; Lipski, 2000, p. 190; Taylor, Lopez, Martínez, \& Velasco, 2012). The terms "Hispanic" and "Latina/o" were introduced to distinguish the population for economic and social reporting purposes (Anwar, 2014; Taylor et al., 2012), the former in 1976, and the latter in 1997 (Taylor et al., 2012).

Neither of these terms is particularly well-suited for such a diverse population. Preference for either "Hispanic" or "Latina/o" may differ regionally within the U.S., with the term of choice being "Latina/o" in coastal urban areas, and "Hispanic" in rural inland areas or southwestern states (Anwar, 2014). Both terms are used by social and commercial organizations (Anwar, 2014). In recognition of the complicated legacy of these terms (Fuhrmann, 2011; Retta \& Brink, 2007), as Portland is a coastal urban area, "Latina/o" will be used where necessary to be consistent with local preferences (Anwar, 2014; Furhman, 2011). 


\section{Chapter 2: Review of Literature}

\section{Multilingualism in Context}

The topics of immigration and English-language learning receive widespread attention today in the United States. Friction around immigration touches upon multiple issues; those of legality, policy, and resource allocation are at the forefront, though broader questions of language, culture, ethnicity, and race are also included. As English language learners in the United States, Spanish-speaking immigrants have a distinct experience in that the Spanish language is a growing presence in the United States (Guskin \& Mitchell, 2016). Evidence to highlight that is the fact that Univision, the largest Spanish-language media company in the country (Matsa, 2015), has a viewership that competes with the English-language broadcasting networks ABC, CBS, and NBC (Guskin \& Mitchell, 2016).

However, Latinas/os, though proportionally the largest group of immigrants and the largest language minority in the United States (Penfield \& Ornstein-Garcia, 1985, p. 19), encounter specific challenges. At worst, the reaction to the rapid growth of the Latino population in particular has included what some believe to be a push for "anti-Latino and anti-immigrant policies" (Amaya, 2013, p. 5), such as the recent discontinuation of the Deferred Action for Child Arrivals (DACA) initiative and, more specifically related to Latinos, border wall construction and the active stifling of the Spanish language (Amaya, 2013, p. 5; Romero, 2017).

Many Americans profess cultural pluralism; even among those who do, however, that ideal doesn't always extend to linguistic pluralism. Many immigrants experience linguistic "policing," or have their private conversations interrupted by 
strangers demanding that they speak English in public (Mason Carris, 2011 pp. 475477). This "English-only" enforcement (Romero, 2017) can take many forms, from signs posted in businesses (Associated Press, 2013), to verbal confrontations in schools ("Hempstead students say", 2013, Ortiz, 2017) and in other public spaces (Caufield, 2015; Hernandez \& Reinstein, 2017; Klemack \& Lloyd, 2015), to physical assaults (Nye, 2013). The sometimes hostile response towards in-practice bilingualism has prompted some to argue that, while in theory, bilingualism would always be an asset to the larger community: in practice, the perceived virtues of bilingualism are contingent upon which of the two languages is the native language, and that native Spanish represents a cultural capital deficit (Amaya, 2013, p. 14).

While, as of 2014, English had been made the official language in 31 states (Liu \& Sokhey, 2014), it is not the official language of the U.S. as designated by the U.S. Constitution, despite some assumptions to the contrary (McKay \& Wong, 2000, p. 1). This reality is not embraced by all and has, in some cases such as those referenced above, become a point of contention (Amaya, 2013; McKay \& Wong, 2000, p.1). In more extreme cases, preference for English monolingualism can become "a litmus test of patriotism" (McKay \& Wong, 2000, p. 1).

It's true, and possibly expected, that immigrants face social, political, and economic disadvantages if they lack proficiency in a dominant language (McKay \& Wong, 2000, p. 1). However, the "English-only" sentiments of many Americans can exacerbate these challenges. As tension mounts, English learners have found themselves the targets of some of "the mainstream population's" or "White 
nativists'” concerns about the increasing diversity in America (McKay \& Wong, 2000, p. 1).

\section{Motivation and the Importance of Community}

Research on maximizing language learning motivation seems to support the importance of different forms of changing cultural or linguistic affiliation, or some degree of "buying in" to experiencing the world through the new language. Motivation has long been recognized as an essential component of $\mathrm{L} 2$ acquisition (Gardner, 1968). The characterization of motivation, however, has changed over time. Motivation has been imagined as a cluster of attitudinal and situational variables (Gardner, 1968, 2001, 2010); as part of a drive to fulfill innate psychological needs (Deci \& Ryan, 2000); as a process of imagining the people we wish to be in the future (Dörnyei, 2009); and as part of identity negotiation within the constructs of the L2 world (Norton Pierce, 1995).

One of the guiding assumptions of this project is that language is social; and social networks, or lack thereof, have a notable effect on motivation (Kim, 2011). As with motivation itself, there have been various ways to account for the targetlanguage community's importance in language learning goals. The influential concept of integrativeness (Gardner, 1968, 2001, 2010) describes a motivational orientation characterized by "a willingness (or desire) to be like valued members of the 'other' language community" (Gardner, 1968, p. 143). Self-Determination Theory's relatedness (Deci \& Ryan, 2000) refers to social group participation as a basic psychological need (Deci \& Ryan, 2000, pg. 253), and as a support of intrinsic 
motivation, or the phenomenon of tasks being undertaken for their own sakes, which is the strongest type of motivation (Deci \& Ryan, 2000, p. 235).

Contributing further to an understanding of the role played by social context in L2 acquisition, the L2 Motivational Self System (Dörnyei, 2009) describes "future self guides," or learners' visions of themselves as successful speakers of an L2, as strong motivators. Inherent in this is identification with the TL community and the desire to be part of it (Dörnyei, 2009, pp. 27-28).

In more recent years, there has been movement toward a sociocultural and sociohistorical (Ushioda, 2009, p. 220) perspective in the field of Second Language Acquisition (SLA) following recognition of the effects of globalization's blurring of 'the target language community' (Dörnyei, 2009, p. 24). Reflecting this move, theories of motivation in L2 acquisition have progressively given more consideration to the importance of social context, and focus on learners "organizing and reorganizing a sense of who they are and how they relate to the social world" through language (Norton Pierce, 1995, p. 18). The concept of investment focuses on this relationship between the learner and their experience of the L2 world, in which learners seek to increase their "symbolic and material resources," or cultural capital (Norton Pierce, 1995, p. 17).

It's true that learning a language involves adopting linguistic and cultural behaviors that can be wholly different from one's own background (Gardner, 2001), particularly when learners already live in the L2 community. And, if it is accepted that social goals can play a role in overall L2 acquisition, then knowing whether 
learners include socially- or community-situated motivations in their own reasons for learning English may assist instructors in helping learners to meet their goals.

\section{Social Context and Linguistic Choice}

As mentioned, sociocultural context has been given more consideration in understanding the realities of language learners. Linguistic choice, such as which language to use, or whether to use a non-standard variety of language, is an important way in which individuals negotiate their roles within that context. Linguistic choices such as these can reflect the intricacies of social relationships. Social markers in language (Laver \& Trudgill, 1979, pp. 25-26) carry information about a speaker on an individual level, including age (Helfrich, 1979), sex (Smith, 1979), socioeconomic status (Rickford \& Eckert, 2002 p. 18), ethnic or racial affiliation (Baugh, 2000; Gatbonton, Trofimovich, \& Segalowitz, 2011), personality traits (Labov, 2001, p. 194), or personal identity (Norton \& Toohey, 2011;

Gatbonton et al., 2011; Shankar, 2008). Speakers don't even need to see each other to draw conclusions about whom they are talking to (Baugh, 2000).

Between individuals, language can be used to express familiarity (Rickford \& McNair-Knox, 1994), power relationships (Norton Pierce, 1995; Norton \& Toohey, 2011), and acceptance into, or rejection from, social groups (Gallois \& Callan, 1991). Speech can also be used by individuals or groups to socially position themselves with respect to others. If a speaker wishes to "show solidarity or gain approval", they may accommodate their speech to the person they're talking with (Giles, Coupland \& Coupland, 1991, p. 19), meaning they might change their own speech 
patterns reflecting that of their conversation partners ( $0^{\prime}$ Grady et al., 2010, p. 609). Conversely, if an individual wishes to distance him- or herself from a certain group, they might be inclined to divergence-differentiating their speech-instead (Zuengler, 1991, p. 232).

There are many reasons why an individual or group would accommodate or diverge in their language with respect to another individual or group. Imitative or modified behavior is often part of learning, as when a learner in the target-language country imitates the linguistic and general cultural behaviors of its residents (Galetcaia, 2014, p. 4271). However, the attitudes of different language communities toward each other can also be a factor (Carpenter \& Hilliard, 2015; Kerevel, 2011, p. 511). Explicit or implicit hostility between groups, for example, might encourage linguistic divergence (Zuengler, 1991, p. 232) to establish social distance (Giles et al., 1991, p. 9; Zuengler, 1991, p. 227). Certain language varieties may carry either overt or covert prestige depending on the context in which they are used (Labov, 2001, p. 217).

The relationship between linguistic features and relational, or situational, context (Biber \& Conrad, 2009, p. 6) is picked up in childhood in both monolingual and bilingual development (Giles et al., 1991, p. 30; Brizuela, Andersen \& Stallings, 1999). Within the language education community, there seems to be at least some interest in making certain aspects of situationally-appropriate language more explicit—such as code-meshing (Paquet-Gauthier \& Beaulieu, 2016) or slang, for example (Chan, 2010; Charkova, 2007; Huang, 2013) — with the aim of facilitating the ease of social adaptation and self-expression. 
Many immigrant language learners in the U.S. must negotiate an "Englishonly" environment (McKay \& Wong, 2000), as well as marked communication and stereotyping based on language characteristics, like accent (Brennan \& Brennan, 1981; Dewaele \& McCloskey, 2013). However, as mentioned earlier, Spanishspeaking English-learners are in a slightly different situation than immigrants from other language backgrounds.

While Latinas/os in the U.S. overwhelmingly agree that English proficiency in the United States is important (Dowling, Ellison \& Leal, 2012), the strength of Spanish in the U.S. (Romero, 2017) and the language varieties arising from contact between English and Spanish represent a particular variety of cultural and linguistic potential experience. Examples of such varieties include: Chicano English (ChE), a Spanish-influenced English dialect spoken by people mainly in California and other southwestern states (Fought, 2005); and Spanglish, which is understood differently by different people (Ardila, 2005; Otheguy \& Stern, 2011; Stavans, 2017) but many take it to mean a mix of English and Spanish (Ardila, 2005).

At present, there seems to be little scholarship devoted to the interaction of English and Spanish in the Pacific Northwest. In 2007, the population of Latinas/os in Oregon accounted for $10.6 \%$ of the state's total (Immigration Policy Center, 2010, p.1). In 2014, the proportion jumped to $12 \%$ of Oregon's population ("Demographic Profile of Hispanics in Oregon," 2017). Latinas/os made up 11\% of the population of Multnomah County ("Multnomah County," 2017), and 16\% of Washington County ("Washington County," 2017), and the state population percentage total is projected to increase to $23 \%$ by 2040 (Rockow, 2014). 
Oregon-based Spanish-language media is also increasing: in 2009, there were seven Spanish-language radio stations broadcasting out of the Willamette Valley, and two more in southern Oregon (Mendoza, 2009). Of course, the hispanophone population in Oregon is not nearly as large in number or proportion (39\%) as in states like California (“Demographic Profile of Hispanics in California," 2017). However, as the number of Spanish speakers grows, it's not difficult to imagine greater contact between cultures and languages in this area in the future. 


\section{Chapter 3: Research Questions and Methodology}

\section{Research Questions}

Research Question 1: Do Spanish-speaking English learners actively recognize and pursue changes to cultural identity?

Research Question 2: Do Spanish-speaking English learners utilize particular learning strategies or resources (specifically, collaborative or individual) to learn about culture, standard English, and non-standard English?

Research Question 3: Do Spanish-speaking English learners perceive standard and non-standard varieties of English, as well as contact language varieties, specifically Spanglish/a mix of English and Spanish, as useful, and do they use them?

Research Question 4: Does 1) the degree of multiculturality, or 2) preference for collaborative language-learning, have a connection to interest in non-standard or non-"classroom" English, or non-standard language in general?

\section{Methodology}

To explore these questions, a survey was developed (see Appendix A) to take a "snapshot" view (Andersen, 2009) of learners' beliefs, attitudes, and selfassessments. It was 10 pages long in its original format, consisted of 63 items, and was modeled after several examples, including Ryder, Alden, \& Paulhus (2000), Andersen (2009), and Zea, Asner-Self, Birman, \& Buki (2003). The survey relied heavily on Likert-scale and "select all that apply"-type items. There was practically no writing required, although participants were often invited to supply their own 
ideas in blank spaces labeled "other." Before distribution, the written survey and consent form were translated into Spanish, and the translations were edited by colleagues (Appendix B).

Both versions were piloted with five Spanish-speaking English learners at Rogue Community College in Medford, Oregon. Following feedback from the pilot study participants, various small changes were made throughout the survey to improve the grammar of the Spanish version, and to emphasize certain words to clarify the questions about students' strategies for learning about culture and nonclassroom English.

Other changes included the expansion of the "Basic Information" section by the addition of spaces for participants to indicate more demographic information, such as their age and gender. As the research questions were developed, items about the applicability of English-Spanish contact language varieties were added: Spanglish was included, as it seemed likely the participants would be familiar with it based on the popular debate on its merits, and, though it is less common in Oregon, questions about Chicano English were also added for comparison with the items about Spanglish.

\section{Survey description}

The following is a description of the survey items grouped by the research question that they address (including the research questions for reference). 


\section{RQ 1: Do Spanish-speaking English learners actively recognize and}

pursue changes to cultural identity?

To learn about participants' current cultural affiliations, a Likert-scale matrix asked respondents to rate the degree to which they felt that they were a citizen of, and part of the culture of, both their home countries and the U.S. (Section B, item number 1, questions 1-8). To access participants' beliefs about the potential to be part of more than one culture simultaneously, the last items in this matrix were Likert-scale statements that multi-cultural affiliation was possible or impossible, respectively (Section B, item 1, questions 9-10).

Multiple items were included to discover participants' interest in learning about U.S. culture. One asked participants to select their reasons for studying English from a list which included both "to learn about U.S. culture" and "to become a U.S. citizen" as options (Section A, item 1). The other was a 'yes/no/I don't know' question directly asking participants about their culture-learning interest (Section B, item 2).

\section{RQ2: Do Spanish-speaking English learners utilize particular learning} strategies or resources (specifically, collaborative or individual) to learn about culture, standard English, and non-standard English?

Participants were given lists of different learning strategies or resources and asked to mark the ones they used. These included strategies or resources that were more collaborative (e.g. "make friends who speak English"), and more individual (e.g. "watch TV or movies in English"), in nature (Section B, items 2-3). An option 
for "other" was also provided, with a blank space for participants to write in their own answers if desired.

To discover whether participants connected learning or using either English or Spanish to learn about culture, the additional strategies of "learning or using English" and "learning or using Spanish" were included in the culture-related survey item. Participants could choose either option, both, or neither.

\section{RQ 3: Do Spanish-speaking English learners perceive standard and non-} standard varieties of English, as well as contact language varieties, specifically Spanglish/a mix of English and Spanish, as useful, and do they use them?

To avoid encumbering the participants with long explanations of "standard" and "non-standard" language or examples, the flexible and all-encompassing label of non-"classroom" English was used in the development of the survey and in participant recruitment. The description of "non-classroom English" provided to participants characterized it as "informal and colloquial varieties of English, including slang and 'bad' words." It was intended to allow the participants to take the basic meaning of "non-standard" language while still being able to move quickly through the survey.

Because recruitment occurred in language classes, participants' familiarity with and use of standard English, or the types of English most commonly taught, was assumed. However, to learn about participants' 'awareness' of different types of English (i.e. their recognition that different types of English exist), participants were given a list of different social contexts ("at work," "in my community," etc.), and 
asked to rate whether the English they learn in class is used "always," "sometimes," "never" therein; or, they could indicate "I don't know" (Section C, item 1).

While it was considered likely that participants would be familiar with the other language varieties in question (Spanglish/a mix of English and Spanish), it was determined that they should be able to report unfamiliarity with these varieties if necessary. For this reason, the survey asked participants about their personal use, and their social networks' use, of these forms. Again, they were asked to specify whether this language was used "always," "sometimes," "never," or "I don't know" in different social contexts. (Section E, items 1-2; Section F, items 1-2). The added items about Chicano English followed the same format (Sections H, I, and J), but the participants overwhelmingly reported that they were unfamiliar with this language variety, and so those items were excluded from analysis.

To learn about the perceived usefulness, or applicability, of non-“classroom" English and Spanglish, participants were given lists of different situations ("communicate at work," "understand TV or movies in English," etc.) and asked to mark those for which knowledge of the language variety in question would be helpful (Section D, item 4; Section G, item 1).

As the participants were actively studying English in classrooms, an additional Likert-scale item was included which asked them to rate their agreement with the importance of learning its non-standard, or non-"classroom," forms (Section D, item 1). 


\section{$R Q$ 4: Does 1) the degree of multiculturality, or 2) preference for}

collaborative language-learning, have a connection to interest in non-standard or non-"classroom" English, or non-standard language in general?

To address the first part of this question, participants' answers about cultural affiliation or belonging (primarily from Section B) were compared with their overall collaborative learning preferences for classroom English (Section A, item 2) and non-classroom English (Section D, item 3).

To address the second part, participants' answers about cultural affiliation or belonging (primarily from Section B) were compared with their answers about the applicability of both non-standard English, and a mix of English and Spanish or Spanglish (Section D, item 4 and Section G, item 1). The former scores (on cultural affiliation or belonging from Section B) were also compared with individual's answers for how important they believed it was to learn about non-"classroom" English (Section D, item 1).

\section{Settings and Participant Recruitment}

With the cooperation of English-language instructors, I visited classes in Portland and surrounding areas, at multiple campuses of Portland Community College, Sponsors Organized to Assist Refugees (SOAR), and Columbia School of English; in Medford, at Rogue Community College; in Gresham, at Mount Hood Community College; in Cornelius, at Centro Cultural; in Newport, at Oregon Coast Community College; in Hillsboro at Adelante Mujeres; and in Washougal, 
Washington, at Hathaway Elementary School which offers adult ESOL classes in a partnership with Clark College.

During my visits, I introduced myself and my project, and invited students to participate. After determining whether the students preferred communication in English or Spanish, I informed the students in the language of their choice that I was working on my final project for my school program, and that I was interested in finding out about how students thought about culture and language-including the kinds of language that people use outside of the classroom. I explained that I was interested in responses only from Spanish-speaking English learners, because as Spanish is the second-most commonly spoken language in the United States, Spanish-speakers are in a different position than other immigrants who are studying English.

In most cases, the students who were interested in participating took their choice of Spanish- or English-language surveys home in pre-posted envelopes to be filled out and mailed at their convenience. In others, teachers extended their class breaks and allowed interested students to use that time to fill out the surveys. A total of 52 surveys were returned: 42 in Spanish, and 10 in English.

In appreciation of participants' time, they had the opportunity to enter themselves into a drawing for a $\$ 25$ Visa gift card. To ensure confidentiality of the responses, the entry forms for the drawing were mailed in different envelopes, to keep identifying information separate from the opinions expressed in the surveys. Additionally, to keep all identifying information secure, all mail was delivered to the Portland State University office of John Hellermann, the advisor for this thesis 
project. That information was stored until the gift card was delivered to the winner and all drawing cards were destroyed.

\section{Participants}

The participants (52; 32 female, 18 male, 2 no response) were immigrants to the U.S.A. who were studying English. Most were from Mexico (44), but there were other countries represented as well: Colombia (1), Guatemala (3), Peru (3), and Venezuela (1). They ranged in age from 18 to 65 years (mean, 35.75; standard deviation, 10.93). Twenty-two participants reported having a beginning level of English proficiency, another twenty-two reported their English proficiency as intermediate, and eight reported their English proficiency as advanced.

To supplement a later survey item on reasons for English study, an item on U.S. citizenship was included. The purpose of this was to ascertain whether any participant who didn't include "to become a U.S. citizen" as a reason for learning English might simply be a citizen already. In recognition of the sensitive nature of this question, participants were reassured in person and in the consent letter that they were free to skip any question on the survey that made them uncomfortable, and were also given the option to indicate they preferred not to answer. As Figure 1 shows, two respondents indicated that they were U.S. citizens, while twenty-five respondents said they were not, and nineteen preferred not to answer. An additional six respondents left the question about citizenship blank. 


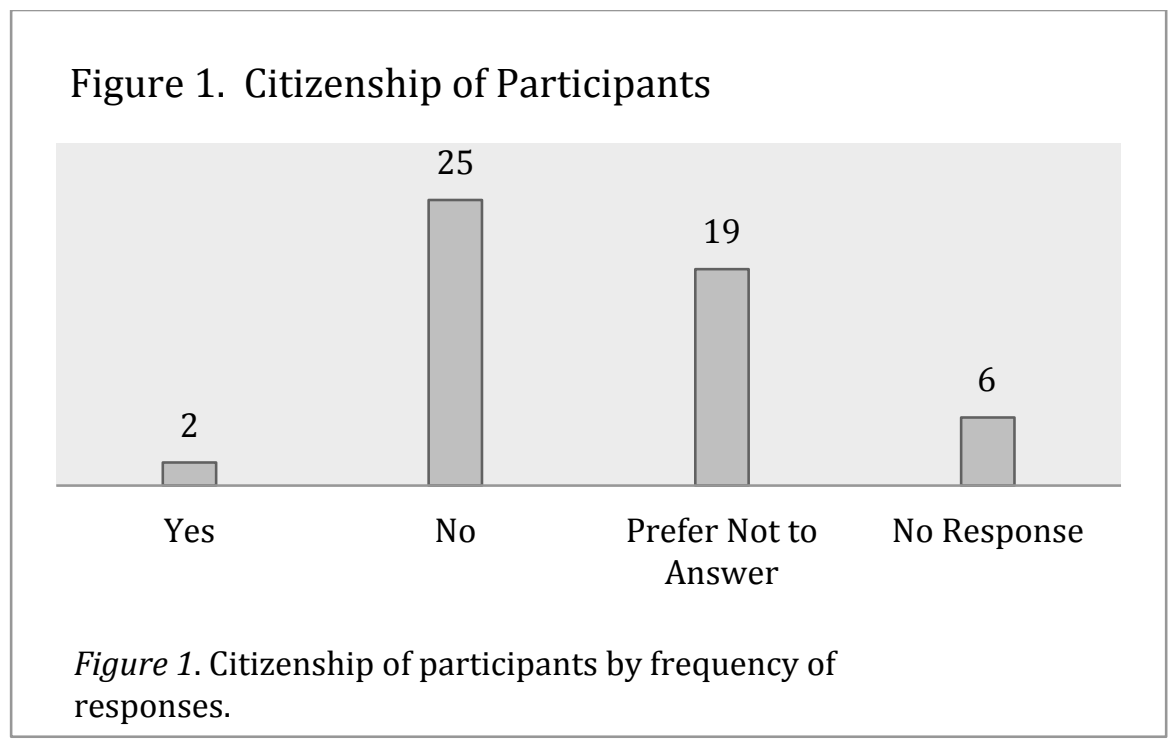

About half of the participants (27) reported having lived in the U.S. for ten or more years, with the next most common length of residence being between one and three years (13). The next lengths of residence in the U.S., in descending order, were: less than one year (6); between seven and ten years (3); between three and five years (1); and between five and seven years (1). One participant did not respond. Though there was some variety in the lengths of residence, as seen in Figure 2, the proportion of people who have been in the U.S. for 10 or more years was striking. 
Figure 2. Participants' Length of Time in the U.S.

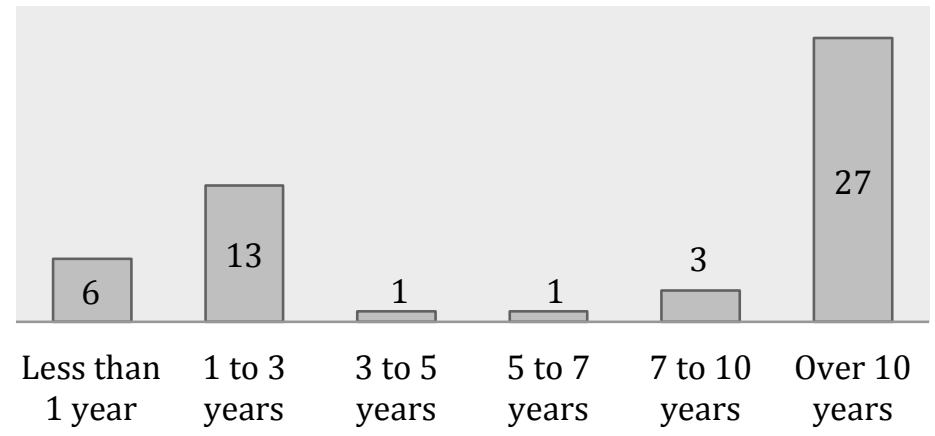

Figure 2. Number of participants who have been in the U.S. for more, or less, than 10 years.

\section{Analytic Methods}

Each completed survey was scored and the data entered into a spreadsheet. The following section describes the scoring for each of the items, again organized into smaller sections with respect to the research questions they address.

\section{Research Question 1}

\section{Interested in learning U.S. culture?}

The total number of participants who selected each reason for studying English was recorded. The number of times "to learn U.S. culture" and/or "to become a U.S. citizen" were selected relative to the other options was noted (Section A, item 1). The question directly asking participants if they were interested in learning about U.S. culture was analyzed by counting the numbers of participants who answered either “yes,” “no,” or “I don’t know” (Section B, item 2). 


\section{Home country/U.S. affiliation}

Participants' answers for the Likert scale questions in Section B, item 1, numbers 1-8 provided numerical scores for the degree of affiliation to country. The four odd-numbered questions pertained to participants' feelings of affiliation with their home countries, and the four even-numbered pertained to affiliation with the U.S. The highest possible score in either category was 16 points. Answers of "I don't know," or items left blank, were eliminated from the individual's total score.

\begin{tabular}{|c|c|c|c|c|}
\hline 4 & 3 & 2 & 1 & 0 \\
\hline $\begin{array}{c}\text { Strongly } \\
\text { agree }\end{array}$ & Agree & $\begin{array}{c}\text { Neither } \\
\text { agree nor } \\
\text { disagree }\end{array}$ & Disagree & $\begin{array}{c}\text { Strongly } \\
\text { disagree }\end{array}$ \\
\hline
\end{tabular}

Because of the different scoring metrics inherent in the different question formats, many of the final scores are represented as percentages for consistency and for comparison purposes. In this case, each individual's final affiliation scores for the U.S. and their home country were represented as percentages of points awarded out of the 16 possible points.

For example, consider Participant A, whose answers for home country affiliation are included below:

\begin{tabular}{|c|c|c|c|c|c|c|}
\hline & $\begin{array}{l}\text { Strongly } \\
\text { agree }\end{array}$ & Agree & $\begin{array}{c}\text { Neither } \\
\text { agree nor } \\
\text { disagree }\end{array}$ & Disagree & $\begin{array}{l}\text { Strongly } \\
\text { disagree }\end{array}$ & $\begin{array}{c}\text { I } \\
\text { don't } \\
\text { know }\end{array}$ \\
\hline $\begin{array}{l}\text { I consider myself a citizen of the } \\
\text { country I am from. }\end{array}$ & $\mathrm{X}$ & & & & & \\
\hline $\begin{array}{l}\text { I believe that I am part of the } \\
\text { culture of my country of origin. }\end{array}$ & & $X$ & & & & \\
\hline $\begin{array}{l}\text { Being a citizen of my country of } \\
\text { origin is very important to me. }\end{array}$ & & & $X$ & & & \\
\hline $\begin{array}{l}\text { Maintaining or developing } \\
\text { cultural practices from my } \\
\text { country of origin is important to } \\
\text { me. }\end{array}$ & & & $X$ & & & \\
\hline
\end{tabular}


This participant receives 4 points for the first item, 3 points for the second, and 2 points for the third and fourth. Their total score for home country affiliation, 11, will be divided by the 16 total points possible. Participant A's final score for home country affiliation, then, is $68.7 \%$. This process is repeated for U.S. affiliation.

I reported these results in the form of a scatter plot, entering each individual participants' scores for their percentage of affiliation to the U.S. on the y-axis, and their percentage of affiliation to their home countries on the x-axis. Participant A's $\mathrm{x}$-axis value would be 68.7, corresponding to their final percentage score for affiliation to home country.

\section{Ability to be part of more than one culture at a time ${ }^{1}$}

To have scores that are comparable across sections, the answers for this Likert-scale question were represented as percentages. Responses of “I don't know," or items left blank, were eliminated from the total score.

\begin{tabular}{|c|c|c|c|c|}
\hline 100 & 75 & 50 & 25 & 0 \\
\hline $\begin{array}{c}\text { Strongly } \\
\text { agree }\end{array}$ & Agree & $\begin{array}{c}\text { Neither } \\
\text { agree nor } \\
\text { disagree }\end{array}$ & Disagree & $\begin{array}{c}\text { Strongly } \\
\text { disagree }\end{array}$ \\
\hline
\end{tabular}

\section{Research Question 2}

\section{Culture -learning strategies}

\footnotetext{
${ }^{1}$ This section included two oppositional Likert-type statements either affirming or denying that belonging to more than one culture at a time was possible. There were little to no appreciable differences in the results between the two items, which often appeared to confuse the respondents. Consequently, only the responses to the first item, which was affirmative, have been included here.
} 
I also reported these results as percentages. Each option in both categories (collaborative and individual) was worth one point. Each participant received two percentage scores of the points awarded out of the 3 points total for each category. Then the numbers of participants who preferred either individual or collaborative, or both equally, were recorded.

\begin{tabular}{|l|l|}
\hline \multicolumn{1}{|c|}{ More collaborative } & \multicolumn{1}{c|}{ More individual } \\
\hline $\begin{array}{l}\text { Working with people who speak } \\
\text { English }\end{array}$ & Use English on the internet \\
\hline $\begin{array}{l}\text { Using English in my community (in } \\
\text { church, in my school or in my } \\
\text { children's school) }\end{array}$ & Watch TV or movies in English \\
\hline Make friends who speak English & $\begin{array}{l}\text { Listen to music, the radio, or podcasts } \\
\text { in English }\end{array}$ \\
\hline
\end{tabular}

For instance, if Participant A selected "Working with people who speak English," "Make friends who speak English", and "Watch TV or movies in English," he or she would be counted as using collaborative strategies of learning (2) more often than individual ones (1). If Participant B marked "Working with people who speak English" and "Watch TV or movies in English," he or she was counted in the number of individuals who use an equal number of individual (1) and collaborative (1) learning strategies.

\section{Language for culture-learning}

The participants were asked to indicate useful languages for learning about culture. This item consisted of the opportunity for participants to mark either "learning or using English," or "learning or using Spanish" as helpful culturelearning strategies. The numbers of participants who responded in different 
manners (marking either the option for English or Spanish, or both, or neither) were counted.

\section{Learning strategies: classroom/standard English}

I reported these results as percentages. Almost identically to the culturelearning survey item described above, each option in both categories (collaborative and individual) was worth one point. Each participant received two percentage scores of the points awarded out of the 4 points total for each category. Then the numbers of participants who preferred either individual or collaborative, or both equally, were recorded.

\begin{tabular}{|l|l|}
\hline \multicolumn{1}{|c|}{ More collaborative } & \multicolumn{1}{c|}{ More individual } \\
\hline Take English classes & Watch TV or movies in English \\
\hline Participate in conversation groups & $\begin{array}{l}\text { Read books, newspapers, or magazines } \\
\text { in English }\end{array}$ \\
\hline $\begin{array}{l}\text { Speak English with my family or } \\
\text { friends }\end{array}$ & $\begin{array}{l}\text { Listen to music, the radio, or podcasts } \\
\text { in English }\end{array}$ \\
\hline $\begin{array}{l}\text { Speak English with the people in my } \\
\text { community (in church or in my } \\
\text { children's school) }\end{array}$ & Use English on the internet \\
\hline
\end{tabular}

\section{Learning strategies: non-classroom/non-standard English}

The results for this item were, again, reported as percentages. The same strategies listed above were provided. Again, each option in both categories (collaborative and individual) was worth one point, and each participant received two scores, for the points awarded out of the 4 points total for each category. The numbers of participants who preferred either individual or collaborative, or both equally, were recorded. Finally, the number of participants who marked the option for "I'm not interested in learning these types of English" was recorded. 


\section{Research Question 3}

\section{Frequency of classroom/standard English}

These results were expressed as a percentage of frequency points awarded by participants according to which classroom English was used "always," "sometimes" or "never" in seven different contexts (for a total possible fourteen points). "The English we learn in class in the U.S. is the same English that my coworkers use," and "The English we learn in class in the U.S. is the same English that people on TV use" are examples of the statements included.

\begin{tabular}{|c|c|c|}
\hline 2 & 1 & 0 \\
\hline Always & Sometimes & Never \\
\hline
\end{tabular}

The participants' scores were then grouped according to whether they attributed low (0.01-33.00 point range), medium (33.01-66.00), or high (66.01100.00) usage frequency to this language variety. Answers of "I don't know" were subtracted from the individual's possible total. For example, if a participant marked "I don't know" for one of the answers, that item would be subtracted from the total, and the final percentage would be taken from twelve points, rather than fourteen.

\section{Importance of knowing non-classroom/non-standard English}

The answers for this Likert-scale question were also represented as percentages for comparability with other scores. The numbers of participants who gave each score, including answers of "I don't know," were recorded. 


\begin{tabular}{|c|c|c|c|c|}
\hline 100 & 75 & 50 & 25 & 0 \\
\hline $\begin{array}{c}\text { Strongly } \\
\text { agree }\end{array}$ & Agree & $\begin{array}{c}\text { Neither } \\
\text { agree nor } \\
\text { disagree }\end{array}$ & Disagree & $\begin{array}{c}\text { Strongly } \\
\text { disagree }\end{array}$ \\
\hline
\end{tabular}

\section{Frequency of contact varieties: Spanglish/a mix of English and Spanish}

Similarly to the frequency scores described above, these results were expressed as percentages of frequency points awarded out of a possible twelve. Answers of "I don't know" were subtracted from the individual's possible total. The participants' scores were again grouped according to whether they attributed low (0.01-33.00 point range), medium (33.01-66.00), or high (66.01-100.00) usage frequency to these language forms. The numbers of participants who indicated that these varieties were not used by themselves or their social networks were also recorded.

\section{Applicability of non-classroom English}

Each of the nine different social situations provided in the list was worth one point. Each participant received a percentage score of points awarded out of the points total. The scores were again grouped according to whether the participant attributed a low (0.01-33.00 point range), medium (33.01-66.00), or high (66.01100.00) applicability to this language variety. The number of participants who chose the option, "I don't think knowing these types of English will help me with any of these things" was recorded. 


\section{Applicability of Spanglish or a mix of English and Spanish}

Nearly identical to the process described above, this item was scored by giving each participant a percentage score of points awarded out of the nine points total. The scores were again grouped according to whether the participant attributed a low (0.01-33.00 point range), medium (33.01-66.00), or high (66.01100.00) applicability to this language variety. The number of participants who chose the option, “I don't think knowing these forms will help me with any of these things" was recorded.

\section{Research Question 4}

To analyze the survey results for the fourth research question, three separate sets of participants' answers from different parts of the survey were compared in the statistics program SPSS to discover whether any statistically significant correlations were present. The first part of the research question was concerned with participants' collaborative language-learning orientations and the degree to which they affiliated with more than one culture at a time. The second part was concerned with the degree to which participants affiliated with more than one culture at a time and their opinions about non-standard language. For each of these ideas, a single score was created for the purpose of comparison.

To create a single "collaborative language-learning orientation" score for the purposes of statistical analysis, the average of each individual's percentage scores on collaborative learning strategies for classroom English (Section A, item 2), and non-classroom English (Section D, item 3), was calculated. To see if a statistically 
significant correlation existed between this "collaborative language-learning orientation" score and certain affiliation orientations, the score was compared with the "derived multicultural affiliation score," described below.

The goal of the "derived multicultural affiliation score" was to arrive at a numerical representation for the degree to which each individual affiliated with both the U.S. and their home country, but not to account for a preference toward either country. First, the average of each individual's scores for percentage of affiliation the U.S. and their home countries (Survey Section B, items 1-8) was calculated. Then, to separate the scores even further, half the difference between the original affiliation scores for the two countries was taken from the average of both. If a participant affiliated substantially more with one culture than another, the final score would be smaller, to indicate a general monocultural affiliation. If a participant had a high score, it was supposed that he or she affiliated strongly with both their home country and the U.S.

To further explain the scoring process, and illustrate the rationale for calculating the scores in such a way, consider the country-specific affiliation scores for Participant A and Participant B, who are both from Mexico:

\begin{tabular}{|l|c|c|}
\cline { 2 - 3 } \multicolumn{1}{c|}{} & $\begin{array}{c}\text { U.S. } \\
\text { affiliation } \\
\text { score }\end{array}$ & $\begin{array}{c}\text { Mexico } \\
\text { affiliation } \\
\text { score }\end{array}$ \\
\hline Participant A & 50 & 50 \\
\hline Participant B & 0 & 100 \\
\hline
\end{tabular}

These two participants will both have an average affiliation score of 50, even though Participant A reported affiliating with both U.S. and Mexican culture, and Participant 
$\mathrm{B}$ reported affiliating with Mexican culture only. To offset this, and to arrive at a numerical idea of the degree to which an individual affiliates with multiple cultures at once, half the difference was taken from the average.

\begin{tabular}{|l|c|c|c|c|c|}
\cline { 2 - 6 } \multicolumn{1}{c|}{} & $\begin{array}{c}\text { U.S. } \\
\text { Affiliation }\end{array}$ & $\begin{array}{c}\text { Mexico } \\
\text { Affiliation }\end{array}$ & Average & $\begin{array}{c}\text { Subtract } 1 / 2 \text { the } \\
\text { original difference }\end{array}$ & $\begin{array}{c}\text { Final } \\
\text { Score }\end{array}$ \\
\hline Participant A & 50 & 50 & 50 & -0 & 50 \\
\hline Participant B & 0 & 100 & 50 & -50 & 0 \\
\hline
\end{tabular}

This final score indicates that Participant A, with a higher number, affiliates with more than one culture simultaneously, or has a "multicultural affiliation." Participant B, whose final score was zero, is represented as affiliating with one culture, or having a "monocultural affiliation."

For the second statistical comparison, corresponding to the second part of the research question, the "derived multicultural affiliation score" described above was compared with a single score representing the participants' beliefs about the applicability of non-standard language, specifically non-standard English (Section D, item 4), and a mix of English and Spanish, or Spanglish (Section G, item 1). To create this "non-standard language value score" for each participant, the average between each individual's applicability percentage scores for 'non-standard English' and 'Spanglish/a mix of English and Spanish' was calculated.

Finally, as an additional comparison between participants' opinions about non-standard language (specifically English, in this case) and their multicultural affiliation, each individuals' "derived multicultural affiliation score" was compared with their scores from the survey item asking if they believed it was important to 
know non-classroom forms of English (Section D, item 1). This was carried out as a third comparison in SPSS.

\section{Additional analysis}

To explore any possible relationships between participants' opinions about non-standard language or their multi-cultural affiliations, and other individual characteristics, several additional sets of variables were analyzed for correlations in SPSS. The "derived multicultural affiliation score" was paired with age, and the "derived non-standard language value score" was also compared with age, and agreement with the statement that it's possible to "be part of more than one culture at a time" (survey Section B, item 9). Finally, as a simpler alternative to the "derived multicultural affiliation score" and the "derived non-standard language value score," participants' responses to the possibility of belonging to more than one culture at a time (survey Section B, item 9) and the importance of learning informal, colloquial, or "bad" types of English (Survey Section D, item 1) were compared. 


\section{Chapter 4: Results}

I report the results of the survey according to smaller questions within each of the research questions they address, in a similar manner as the previous section.

\section{Research Question 1}

\section{Interest in learning U.S. culture}

Forty-eight participants (97.9\% of those who responded to this item), answered affirmatively to the question about whether they were interested in “learning about or participating in" U.S. culture. One participant (2.0\%) answered "no," and three did not respond. No participant selected the option for "I don't know."

As shown in Table 1, the most commonly-selected reasons for learning English were "To improve basic skills/continue with education" and "To speak with people in my community (in church, at work, and/or in my children's school)." "To learn U.S. culture" was the third-most popular, with 31 individuals (59.6\%) including that in their list. 
Table 1. Reasons for Learning English

\begin{tabular}{|c|c|}
\hline & $\mathrm{n}$ (percentage) \\
\hline $\begin{array}{r}\text { To improve basic skills/continue } \\
\text { with education }\end{array}$ & $41(78.8)$ \\
\hline $\begin{array}{l}\text { To speak with people in my } \\
\text { community (in church, at work, } \\
\text { and/or in my children's school) }\end{array}$ & $39(75.0)$ \\
\hline To learn U.S. culture & $31(59.6)$ \\
\hline To find work & $30(57.6)$ \\
\hline To make new friends & $22(42.3)$ \\
\hline To speak with family or friends & $20(38.4)$ \\
\hline To become a U.S. citizen & $19(36.5)$ \\
\hline
\end{tabular}

Table 1. Reasons for English-learning, in descending order of frequency.

\section{Ability to be part of more than one culture at a time}

Thirty-nine respondents (84.7\%) indicated they agreed or strongly agreed with the statement that someone can belong to more than one culture at a time. Four (8.6\%) said they neither agreed nor disagreed with the statement, and two (4.3\%) said they disagreed or strongly disagreed. One participant (2.1\%) indicated "I don't know," and six didn't respond.

\section{Home country/U.S. affiliation ${ }^{2}$}

Figure 3 shows each individual's reported affiliation percentage scores. U.S. affiliation scores are located on the y-axis and home country affiliation scores are located on the $\mathrm{x}$-axis. There is a visibly high amount of variation in U.S. affiliation

\footnotetext{
2 The survey also asked participants to indicate their "linguistic identity" to explore a possible connection with cultural identity. The responses given showed no clear pattern. As such, they were excluded from this project.
} 
scores, and even seven participants who gave higher scores for the U.S. than for their home countries. However, it is notable that no participant gave a home country affiliation score of less than $50 \%$. Thirteen participants reported an equal affiliation to both countries.

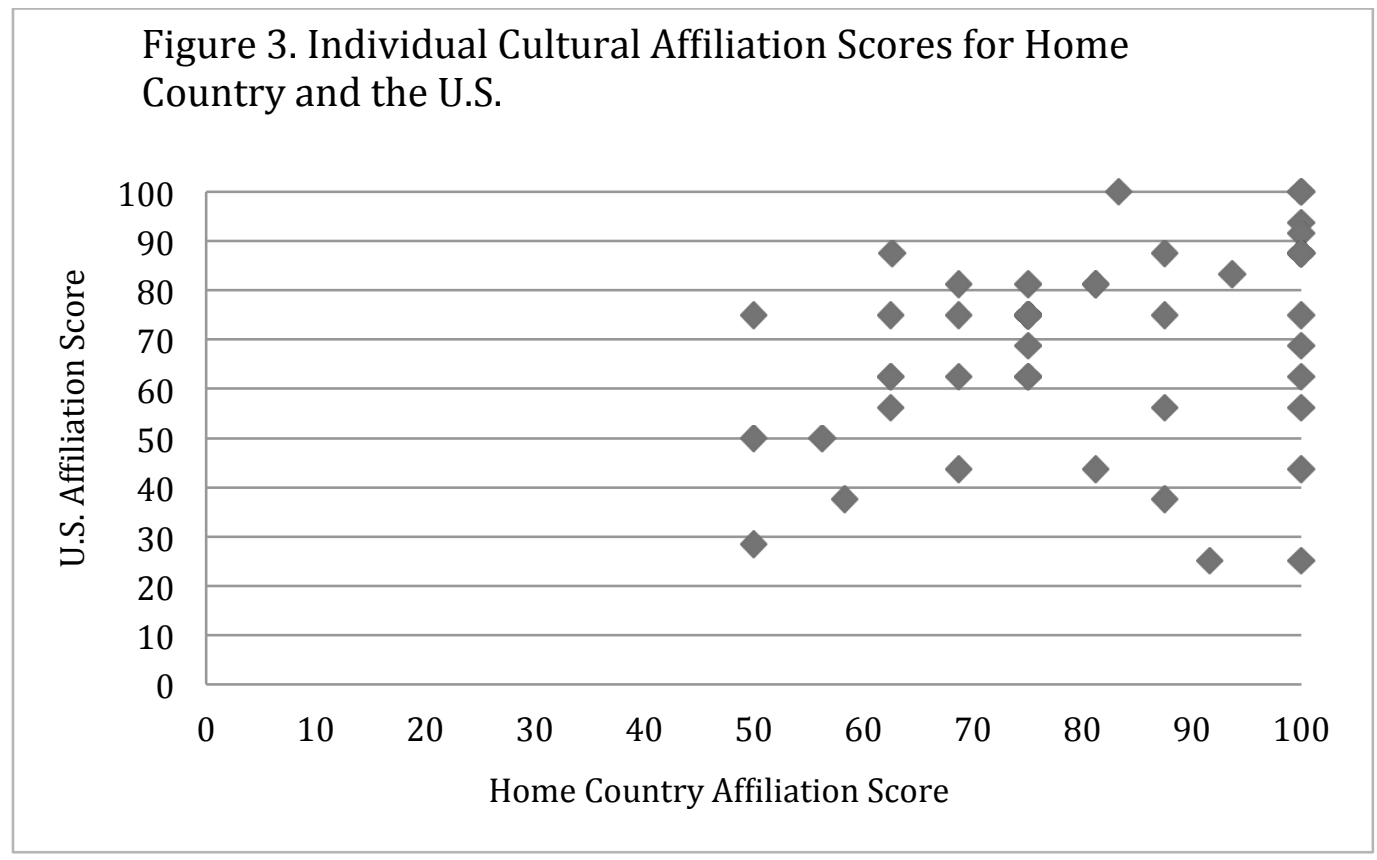

Figure 3. Individual affiliation scores, with U.S.-affiliation on the $\mathrm{y}$-axis and home country affiliation on the $\mathrm{x}$-axis.

\section{Research Question $2^{3}$}

\section{Culture-learning strategies}

Figure 4 shows that, overall, there was not much variation in the numbers of participants who favored either individual or collaborative learning strategies, or an

\footnotetext{
3 In the items concerning culture and non-standard English, participants were asked about learning strategies that they thought would potentially be helpful, and learning strategies they actually used. The responses revealed no clear differences. For this reason, and to have comparable results, the "potential learning strategies" results were excluded from this project.
} 
equal combination of the two. One participant reported they were not interested in learning U.S. culture and was directed to skip this section, and one participant didn't respond.

Figure 4. Preferred Learning Strategies:

U.S. Culture

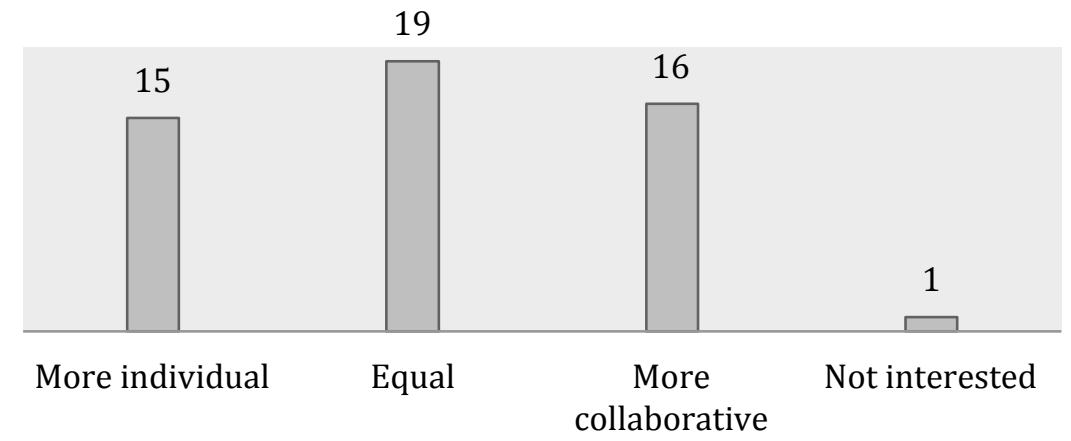

Figure 4. Participants' preferred U.S. culture learning strategies or resources, by frequency of responses.

\section{Culture-learning language}

Of the forty participants who included learning or using a language as a strategy for learning about U.S. culture, most respondents (37, or 92.5\%) selected "English" as a helpful language for learning about culture. In contrast, only three (7.5\%) selected both "English" and "Spanish", and no participants selected "Spanish" only.

\section{Learning strategies: Classroom English}

As Figure 5 shows, almost half (twenty-five, or $49.0 \%$ ) of the participants reported favoring individual strategies over collaborative for learning standard, or 
"classroom," English. Slightly fewer participants favored collaborative strategies exclusively over using collaborative and individual strategies equally.

Figure 5. Preferred Learning Strategies:

Standard English

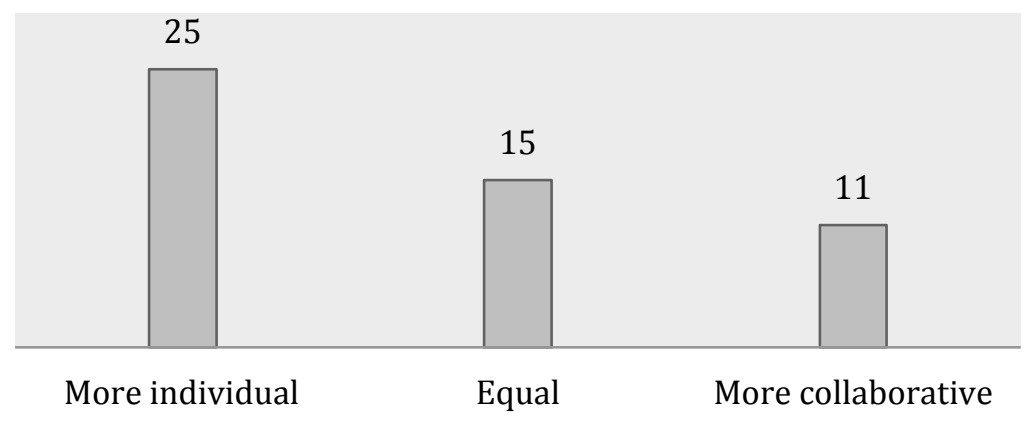

Figure 5. Participants' preferred standard English learning strategies or resources, by frequency of responses.

\section{Learning strategies: Non-classroom English}

Figure 6 shows that, again, more participants (twenty-one, or 42.0\%) prefer individual learning strategies for learning about non-standard varieties of English. Thirteen (26.0\%) reported using more collaborative learning resources; and four $(8.0 \%)$ reported using an equal number of both. Twelve $(24.0 \%)$ indicated that they were not interested in learning these forms of English. 
Figure 6. Preferred Learning Strategies: NonStandard English

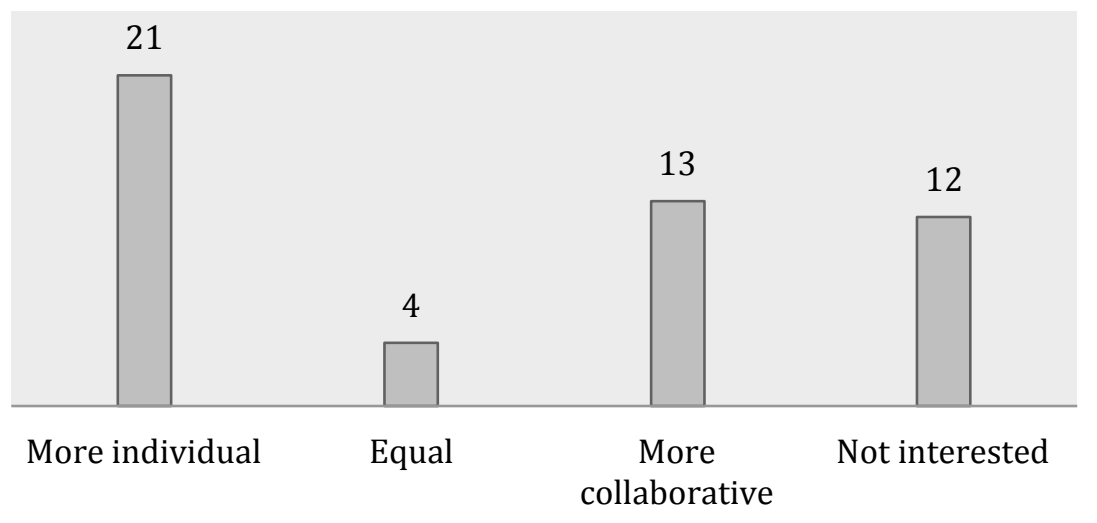

Figure 6. Participants' preferred non-standard or non-"classroom" English learning strategies or resources, by frequency of responses.

\section{Research Question $3^{4}$}

\section{Usage frequency: classroom/standard English}

As can be seen in Figure 7, very few participants gave standard, or classroom, English a low usage score. Slightly more participants gave high-range usage scores than medium ones. Of the participants who gave standard English a usage score in the high range, four (7.8\%) gave scores of 100, indicating standard or "classroom" English was used one hundred percent of the time in all contexts given.

\footnotetext{
${ }^{4}$ The survey also asked participants about Spanish-influenced dialects of English, like Chicano English or similar varieties. Only 10 of the 52 respondents reported that they used these language varieties, and only 15 reported that their social networks did. It was thus determined that these particular items were not relevant for these participants, and the results were excluded.
} 
Figure 7. Language Use Frequency: Standard English

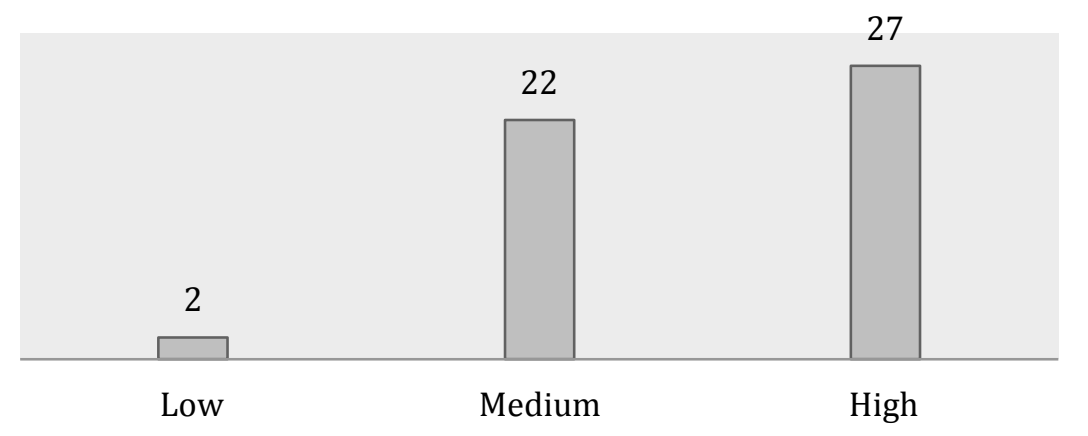

Figure 7. Reported usage of standard or "classroom" English, by frequency of score ranges.

\section{Usage frequency: Spanglish/a mix of Spanish and English}

As Figure 8 indicates, the use of "Spanglish/a mix of English and Spanish" is fairly evenly distributed, with most participants (about $50 \%$ ) giving a medium usage frequency score for themselves and their social networks. Additionally, participants generally gave slightly lower scores for personal use than for their social networks' use.

Figure 8. Language Use Frequency: Spanglish/mix of English and Spanish

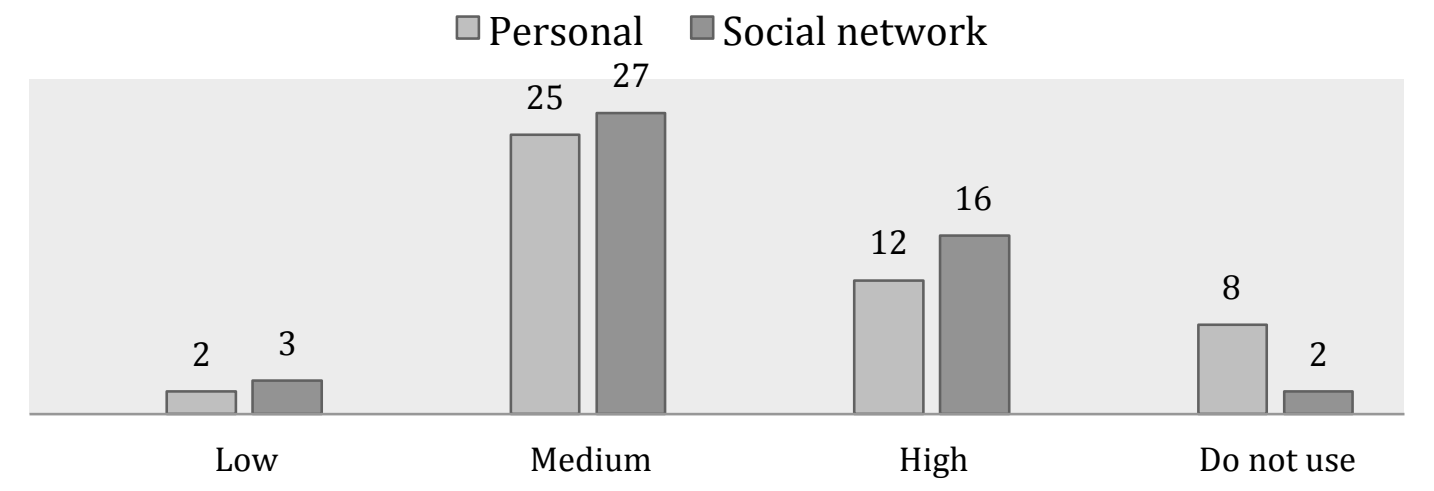

Figure 8. Reported usage by participants and their social networks of Spanglish/a mix of Spanish and English, by frequency of score ranges. 


\section{Importance of knowing non-classroom/non-standard English}

About half the participants (twenty-six, or 50.9\%) reported that they "agreed" or "strongly" agreed that it was important to know informal and colloquial types of English, including "bad" words. Seven (13.7\%) reported they neither agreed nor disagreed; and twelve (23.5\%) indicated they disagreed or strongly disagreed. Six participants (11.7\%) answered, “I don't know," and one participant didn't respond.

\section{Applicability of non-standard English and Spanglish/a mix of English and}

\section{Spanish:}

As Figure 9 shows, the number of participants who gave both language varieties a low applicability score and the number who gave scores of zero are quite similar. Fewer participants considered either language variety to have either a medium or high amount of applicability in different contexts. 
Figure 9. Language Variety Applicability: Non-Standard English and Spanglish/Mix of English and Spanish

$\square$ Non-standard English $\square$ Spanglish/mix of English and Spanish

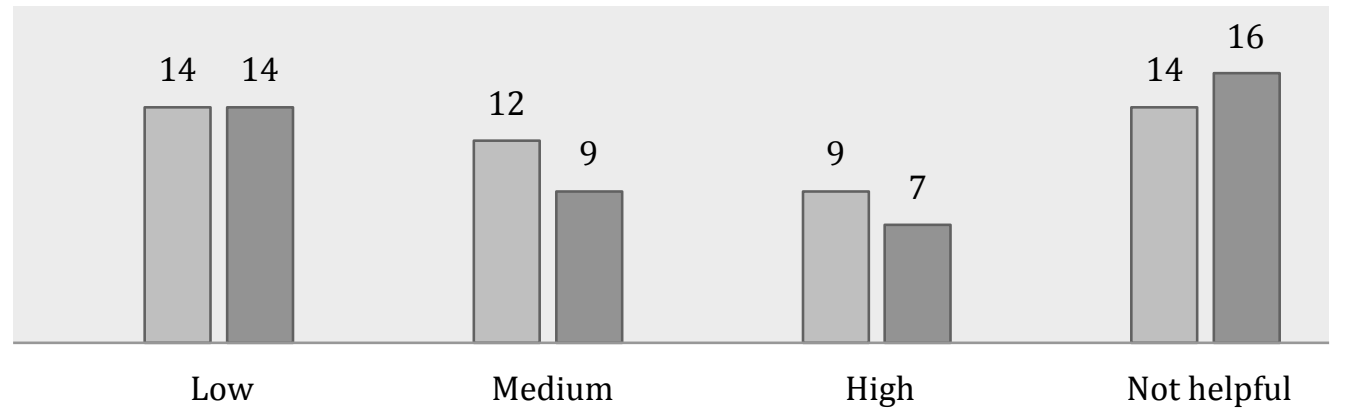

Figure 9. Participants' applicability scores awarded to non-standard English and Spanglish/mix of English and Spanish, by frequency of score ranges.

\section{Research Question 4}

Connections between collaborative language-learning strategies and multicultural affiliation

There was no statistically significant relationship between individuals' "collaborative learning orientation" scores and their "derived multicultural affiliation" scores.

\section{Connections between cultural affiliation and non-standard language}

\section{beliefs}

A moderate negative correlation (Spearman $\rho=.521$ ) that was statistically significant $(\mathrm{p}=.001)$ was found between the degree to which participants had a 
multicultural affiliation and their beliefs about the importance of knowing nonstandard forms of English (survey Section D, item 1). There was no statistically significant relationship between individuals' "derived multicultural affiliation scores" and their "derived non-standard language value" scores.

\section{Additional correlations}

There were no statistically significant correlations between any of the other variable pairs. 


\section{Chapter 5: Discussion and Limitations}

This project elicited opinions from English-learners from a particular demographic: Spanish-speaking immigrants from Mexico and Central and South America. These participants were selected because of their unique position among immigrant English-learners in the U.S., sharing the second-most common language in the country. The topics of interest were language value and potential multicultural affiliation, the inclusion of socially- or community-based goals in learning motivation, and the use of collaborative learning strategies.

\section{Cultural affiliation-Current Feelings, Goals for the Future}

The first area of inquiry was participants' cultural identities, and whether the participants intended to change or add to them. The survey attempted to answer this question by directly asking respondents: 1) if they affiliated with U.S. culture; 2) if they believed multicultural affiliation was possible; and 3) whether cultural participation or learning was part of their motivation for English study.

The results showed that feelings of affiliation to multiple cultures were different for each individual, but generally there was an openness and an interest in learning about or participating in U.S. culture. Although these participants, as a group, were more affiliated with their home countries, nearly all participants recognized at least partial affiliation with the U.S., and many participants (39, or $84.7 \%$ ) indicated a belief in the possibility of being part of more than one culture at a time. Additionally, "to learn about U.S. culture" was the third-most commonly 
selected reason for studying English, while "to speak with people in my community" was the second-most commonly selected reason.

Given that this group is comprised of people actively studying a language, and includes many (27, or over half) who have lived in the U.S. for ten or more years, these results were unsurprising. While adult students must face a number of challenges in order to persist in language study, including obligations to family, social networks, jobs, access to regular transportation, and affective considerations (Ortega, 2008), the individuals in this sample have clearly had enough time and resources to feel a connection to the local culture. Without knowing any other details about the lives of the participants in this project, it speaks to a certain degree of success in the U.S. that they are able to enroll in and attend ESOL classes, and may further account for the experiences informing the ideas of these participants.

\section{Learning Strategies: Collaborative versus Individual}

The second goal of this project was to learn more about whether learners preferred collaborative or individual learning strategies to learn about three different topics: culture, standard or "classroom" English, and non-standard, or non"classroom" English. The survey attempted to explore this question by asking respondents to choose their own preferences from lists of common learning strategies that were either more collaborative or more individual in nature. In interpreting these results, it is important to note that no information regarding the frequency or consistency of learning strategy use was elicited from participants, so these findings do not represent a comprehensive picture of the efforts these 
learners undertake to acquire English. Due to the importance of social goals in language learning (Gardner, 1968; Norton Pierce, 1995), the focus of this project was on the use of collaborative learning strategies, and the ratio of collaborative strategies to individual ones.

Collaborative strategies emphasizing communication with social networks (e.g. "speaking English with my family and friends") had the highest reported usage rate for learning about culture-meaning a higher number of people used them equally as often, or more often, than individual strategies (See Figure 4). This finding supports the link between language use and culture learning (Risager, 2007).

When it came to learning language specifically, I initially thought that nonstandard English would see a higher instance of collaborative strategy preferences, owing to the social functions for which it can be utilized. Additionally, the social component recognized in SLA motivation theories, and the relatively large percentage of participants who included socially-situated motivations, contributed to the imagined higher instance of collaborative learning preferences. However, this was not borne out by the results: In fact, it was the opposite. Individual strategies like media use (e.g. watching TV or reading magazines) were preferred (see Figures 5 and 6). This was true for both classroom and non-"classroom" English, and is consistent with the known realities of the life of an adult ESOL student, who has other responsibilities to manage outside of class, and pursues language education as their schedules and resources permit. 
Two additional features of these results stood out. First, the relatively large number of those who favored collaborative strategies more than or equal to individual ones for learning about culture may suggest a stronger connection between culture and social participation in the minds of the participants. Second, there were very few participants-only four-who reported using an equal number of collaborative and individual strategies to learn non-standard English. In contrast, fifteen people reported using an equal number of collaborative and individual strategies to learn standard English. However, given the constraints presented by the format of the survey items, more investigation is needed to determine whether this might be indicative of any substantial difference in approach to learning about standard and non-standard English.

\section{Language Beliefs-Standards and Attitudes}

The third question explored by this project was about learners' perceptions of the utility of standard and non-standard language, the latter category including both English and a mix of English and Spanish, or Spanglish. To answer the third research question, participants were first asked to report on their awareness of different language varieties used in different situations. Participants were also asked to rate their agreement with the statement that it's important to learn nonstandard English. Finally, participants were asked to choose the number of uses for which they thought non-standard English and a mix of English and Spanish, or Spanglish, would be helpful. 
The first results showed respondents clearly have an awareness of using language with different characteristics in different situations. Few rated classroom English "low" in usage frequency, but few also reported using it 100 percent of the time. Spanglish, or "a mix of English and Spanish" generally received lower usage frequency ratings than classroom English, though most participants reported that both they and their social networks used it at least sometimes. Given that the awareness of different features of language used in different situations develops early in life (Brizuela et al., 1999; Giles et al., 1991) it is unsurprising that the participants would answer in this way-especially these individuals, who have spent such considerable time living in an English-majority country.

The results from the survey items on non-standard language usefulness, or applicability, suggest that the participants generally don't regard these varieties as potentially helpful. The most common scores, given by 28 participants to nonclassroom English, were either in the low range, or were scores of zero, indicating the participants didn't think it would be useful at all. Conversely, nearly that same number (26) agreed or strongly agreed that knowing non-classroom English was important.

English, as it is understood by traditional educational practices and often by popular discourse as well (DeVoe, 2017; MuCulloch, 2014; Paquet-Gauthier \& Beaulieu, 2016) is of a particular 'standard' type. Discussions about what constitutes 'correct' English and its mastery, though hardly new, arise in response to new iterations or manners of usage. These views of language have been criticized by some linguists and language educators for the perceived lack of recognition of 
the demands of different communicative contexts (Paquet-Gauthier \& Beaulieu, 2016), as well as being tied to prejudice (Paquet-Gauthier \& Beaulieu, 2016).

It is well-established that English acquisition is linked to more opportunity and more social capital in the minds of immigrants and language-learners (Dowling, Ellison \& Leal, 2012; Norton Pierce, 1995). A potentially illustrative example from these findings is that when participants were asked to select which language(s) would help them learn about U.S. culture, and given both English and Spanish as choices, only 3 selected both languages, and none selected Spanish alone. This suggests a strong connection between English and U.S. culture-possibly even to the point of not recognizing the role that Spanish and Spanish-English bilingualism actually play in the culture of the U.S. This may be a testament to the strength of the "English-only" message being advanced by some (McKay \& Wong, 2000); or, it could simply be attributed to the importance of English acquisition in the lives of the participants.

Returning to language applicability, similarly to those of non-"classroom" English, the most common scores given to Spanglish or a mix of English and Spanish were either in the low range, or were scores of zero, indicating the participants didn't think it would be useful. Spanglish, like non-“classroom" English, represents a non-standard and, according to some, an "incorrect" way of speaking (Ardila, 2005; “Encuesta: ¿Que opines del Spanglish?," 2010). The absence of a popular, agreedupon definition of what Spanglish is (Ardila, 2005; Otheguy \& Stern, 2011; Stavans, 2017), contributes to questions about its legitimacy as a communicative system. 
However, linguistics and language education have seen an increase in embracing multilingualism, which is inclusive of students' first languages and codemixing or code-meshing behaviors, as a pedagogical approach (Haukås, 2016; Paquet-Gauthier \& Beaulieu, 2016). The incorporation of multilingual instructional practices is thought to acknowledge the fluidity and complexity of the experience of multilingual development, and the communicative reality of speakers of more than one language (Haukås, 2016; Paquet-Gauthier \& Beaulieu, 2016).

The different realities and roles of the language systems of English, including its non-standard forms, and Spanglish, made the similarity of the applicability scores for non-classroom English and Spanglish especially interesting. It was initially thought that perhaps there might be more difference, in accordance with different motivations of the participants for learning English, or in accordance with the practical communication needs of the participants.

One potential explanation for the similarity is language prescriptivism, which is very much a part of conversations about English (DeVoe, 2017; MuCulloch, 2014), and Spanish or Spanglish (“Encuesta: ¿Que opines del Spanglish?," 2010; Stavans, 2017). A few participants displayed such opinions themselves in such comments as, "Creo que hay que aprender a utilizar el idioma de forma correcta [I believe one must learn to use language correctly].” It may also be an effect of language classes, which do not always include non-standard or non-prestige forms of language (Charkova, 2007, Paquet-Gauthier \& Beaulieu, 2016); though, as discussed earlier, multilingual pedagogy and the encouragement of broader language attitudes may be incorporated more regularly in the future (Haukås, 2016). 
Whatever the reason for these responses may be, the generally low potential usefulness attributed to the varieties in question was of interest, particularly taken with the large percentage (75\%) of respondents who included the sociallymotivated "to speak with people in my community (in church, at work, and/or in my children's school)" as one of their goals for learning English, and the social functions of the use of different language characteristics (Mason Carris, 2011; Mori, 2014). This may suggest a potential, again, for the benefit of incorporating more inclusion of attitudinal components (Paquet-Gauthier \& Beaulieu, 2016) and focus on proactive multilingualism into language curricula (Haukås, 2016).

\section{Multiculturality and the Importance of Non-Standard English}

The last research question explored by this project was whether there would be any correlations between particular attitudes toward collaborative language learning and multiculturality, and between multiculturality and attitudes toward non-standard language. The responses from participants on different areas of the survey were isolated and combined into pairs, and checked for statistically significant correlations using the non-parametric Spearman test. As the scores were created using imprecise, exploratory metrics representing complex social and individual experiences, it is necessary to view the interpretation of these data, and the discussion of these findings, through the recognition of their limitations.

This result of the comparison between multicultural affiliation and nonstandard English (negative correlation) showed the opposite of what was expected. I had imagined that those with a higher degree of multicultural affiliation would 
potentially be more invested in social relationships in either or both cultures, and that because of the socially-situated importance of language choice, there would, by extension, be a greater interest in those language forms. Instead, a moderate negative correlation between multiculturality and perceived importance of knowing non-standard English suggested that a higher score in one of these areas may be loosely connected with a lower score in the other.

As mentioned earlier, the discussion on the validity of different types of language permeates many different social and cultural spheres, including ESOL classrooms. The presence or absence of different language characteristics may reinforce certain conclusions about their usefulness. Alternatively, or perhaps additionally, individuals who show higher multicultural affiliations may be more invested in the prestige varieties of culture and language. Nevertheless, although the correlation went in the opposite direction of what was assumed, it supported the notion that there may be a relationship between the degree to which one feels part of more than one culture at a time and different opinions about language. The reasons behind these results, however, remain unaccounted for, and may be of interest for future study.

\section{Limitations}

There were a number of limitations inherent in this project. While the information the survey attempted to elicit was based on previous research, and the survey itself was piloted, some items in the survey were vague and subjective, which at best left much open to the interpretation of individual participants, and at worst 
confused them. Such problem items included: the question about participants' "linguistic identity," which may have been unclear; questions relating to "a mix of English and Spanish, or Spanglish," the latter term meaning something different to different groups of people; and, questions relating to "varieties of English that have been influenced by Spanish, like Chicano English or similar," which was entirely unfamiliar to many participants. The relevance of some of these survey items, such as the ones pertaining to $\mathrm{ChE}$ or similar language varieties, should have been determined more accurately.

Additional limitations include the sample size of 52, which is a small one for survey- or questionnaire-based research. Self-reported data are not as reliable as data of other kinds (Perry, 2005) The effects of researcher influence (Perry, 2005) must not be discounted, as I recruited participants entirely in a face-to-face manner, and potential and actual participants received a lot of information about me and my own demographic- and community- affiliations. Finally, though this project was exploratory, controlling for various characteristics in participant recruitment—such as age, citizenship status, length of time in the U.S., or current English-learning institution, would have strengthened the research. 


\section{Chapter 6: Implications and Conclusion}

The next section explores possible implications of the above results. These largely relate to instructional approaches in two areas: language attitudes, and the linguistic and cultural identities students bring with them to the classroom. Neither of these areas have traditionally been the focus of ESOL instruction. However, there may be value in their consideration (Harper \& de Jong, 2004; Lasagabaster, 2017; Mori, 2014; Paquet-Gauthier \& Beaulieu, 2016), according to the discretion of the teachers, and their assessment of what is best for their students.

\section{Language Attitudes}

Most participants could think of few, if any, potential applications for nonstandard forms of English, and only about half of the participants in this project thought it was important to know these forms. However, nearly two-thirds of the same participants gave community participation as a reason for studying English, and all but one indicated they were interested in learning about U.S. culture.

As mentioned in the literature review, the choice to use different varieties of language, including non-standard ones (Carpenter \& Hilliard, 2005; Gallois \& Callan, 1991; Gatbonton et al., 2011), is made in accordance with different social purposes. Furthermore, social experience or goals have been established as an important factor in language learning motivation (Deci \& Ryan, 2000; Gardner, 2010; Dörnyei, 2009; Norton Pierce, 1995). In the last few decades there has been an increased amount of attention on the complex realities of communication in multilingual societies (Haukås, 2016; Paquet-Gauthier \& Beaulieu, 2016), and the interaction of 
language beliefs or attitudes with learning outcomes (Lasagabaster, 2017; PaquetGauthier \& Beaulieu, 2016).

Research has suggested that positive language attitudes encourage motivation to learn (Lasagabaster, 2017), and argued the benefits of incorporating attitudinal components to language curricula (Lasagabaster, 2017; Paquet-Gauthier \& Beaulieu, 2016). Inclusion of language attitudes in classroom discussions could open the door for further discussions on the "wide variety of communicative situations that call for different usage norms" (Paquet-Gauthier \& Beaulieu, 2016, p. 170). In a more immediate sense, language attitudes, including language prestige, are also a facet of culture, and thus would be relevant to those students for whom culture is an interest. Both of these potential outcomes may enable students to develop tools to reach their goals, particularly socially- or community-oriented ones.

\section{Student Language and Cultural Identities}

Research has shown that use of student L1s can help facilitate the acquisition of a new language (Castaneda, 2017). At the same time, the demand for multilingual people in the U.S. workforce is only growing (Ben-Ghiat, 2015), and the interest in multilingual pedagogy is growing as well (Haukås, 2016; Lasagabaster, 2017; Paquet-Gauthier \& Beaulieu, 2016). Spanish, in particular, is in a unique position because of the large population in the U.S. with it as part of their linguistic or cultural legacy. Yet, many challenges exist in considering the role that Spanish or other languages can or should have in ESOL classes. 
First, ESOL classes are constrained by the language proficiencies of the people within them. Even if an instructor shares a language in common with some of his or her students, it is often the case that this won't be true with other students. Other constraints include teacher training and resources (Haukås, 2016) and popular belief in the oft-repeated myth that immersion or contact with an L2 is sufficient to learn another language (Harper \& de Jong, 2004).

Still, as mentioned above, other perspectives argue for greater inclusion of multifaceted student identities, and the importance of the various "selves" in language learning, including the selves that students arrive with, formed in their home cultures and original languages (Mori, 2014; Norton \& Toohey, 2011). The findings of this project may support this, given that the respondents reported variable levels of affiliation with the U.S., but none reported less than $50 \%$ affiliation with their home countries. Indeed, as language is so inextricably connected to identity, the question of how and to what degree students can benefit from utilizing their multiple selves (Castaneda, 2017; Mori, 2014) will undoubtedly persist.

It must also be noted that the increasing tension surrounding immigration and multilingualism provides an emotionally-charged environment that also impacts ESOL classes. As has been established, language learning does not occur in a vacuum, completely separate from social context (Norton Pierce, 1995) and the dynamic between first language and target language is negotiated both in the classroom (Castaneda, 2017; Mori, 2014; Ortiz, 2017) and outside of it (Hernandez \& Reinstein, 2017; Norton Pierce, 1995). The interaction of students' goals (whether linguistic, social, or cultural) and the sociocultural state of the English- 
speaking world may have implications for certain educational contexts-for instance, ones in which students may be served by the incorporation of critical pedagogy and examinations of these issues.

\section{Conclusion}

This project explored multicultural identity, collaboration in learning, nonstandard language, and any relationships between them as they are experienced by a small sample of Spanish-speaking English-language learners from Mexico, Central America, and South America. The study chose to investigate these matters with speakers of Spanish because it is the second-most commonly spoken language in the United States, and represented in a growing number of cultural spheres. The information obtained that supported the known experiences of adult ESL students in general included the variability of multicultural affiliation, preference for individual strategies for language-learning, and the overall low attribution of the utility of nonstandard language. The results also suggested a possible negative correlation between the extent to which one affiliates with more than one culture at a time, and the perceived importance of knowing non-standard English.

The research is limited in the degree to which the findings can be generalized. Yet, there may be more to investigate, such as whether the correlation suggested by this research bears out in larger, more controlled population samples, and more consistent research methods. It may also be interesting to learn the reasons behind adult English learners' evaluations of non-standard English. Initially, this project came out of my own experiences as a language teacher, and 
hearing students claim that they "only want to learn the correct way to speak." Perhaps there is more to be learned about what this means to the resident adult students pursuing English acquisition.

Several years have passed since I started working on this project. The cultural conversations surrounding English, Spanish, and English-Spanish bilingualism in the United States may have changed in subtle ways during this time. When I began, I hadn't anticipated an environment in which I could be turned away from visiting a classroom to invite Spanish-speaking students to participate in my project because my visible identity as a White, English-speaking stranger might sufficiently intimidate the students into not returning to the class. As the current social context affects the needs of the students, it remains to be seen what sort of decisions instructors will need to make in order to help their students meet their goals. It also, of course, affects the notions of "correctness" of language and culture, and what is made possible by learning it. This will certainly be a challenge for linguists and language teachers who value multilingualism and multiculturalism, and who see the use of an understanding of both as an aid in learning English. 


\section{Sources}

Amaya, H. (2013). Citizenship excess: Latino/as, media, and the nation. New York: New York University Press.

Andersen, C. (2009). A sociolinguistic survey of language behaviours and attitudes in nain, nunatsiavut (Order No. MR64778). Available from ProQuest Dissertations \& Theses Global. (746819340). Retrieved from http://stats.lib.pdx.edu/proxy.php?url=/docview/746819340?accountid=13 265

Anwar, Y. (2014). I say Hispanic. You say Latino. How did the whole thing start? UC Berkeley News Center. Retrieved from http://newscenter.berkeley.edu/2014/04/29/hispanic-label/

Ardila, A. (2005). Spanglish: An Anglicized Spanish dialect. Hispanic Journal of Behavioral Sciences, 27(1), 60-81. doi: 10.1177/0739986304272358 Associated Press (2013). Philly officials warn eatery for English-only sign. NBC News. Retrieved from http://www.nbcnews.com/id/13272368/ns/ us_news-life/t/philly-officials-warn-eatery-english-only-sign/\#.Vp7vpaQflB9 Baugh, J. (2000). Racial identification by speech. American Speech, 75(4), 362-364. Retrieved from http://web.b.ebscohost.com.proxy.lib.pdx.edu/ ehost/pdfviewer/pdfviewer?sid=ddec42ce-a6b1-4bb3-9c3fda4c0ce658ba\%40sessionmgr114\&vid=3\&hid=115

Bedolla, L.G. (2006). Rethinking citizenship: Noncitizen voting and immigrant political engagement in the United States. In T. Lee, S. Karthick Ramakrishnan, \& R. Ramírez (Eds.), Transforming politics, transforming 
America: The political and civic incorporation of immigrants in the United States (pp. 51-70). U.S.A: University of Virginia Press.

Ben-Ghiat, R. (2015, September 17). Why it's good to speak Spanish in America. CNN. Retrieved from http://www.cnn.com

Biber, D. \& Conrad, S. (2009). Register, genre, and style [Adobe Digital Editions version]. Cambridge: Cambridge University Press. Retrieved from http://reader.eblib.com.proxy.lib.pdx.edu/\%28S\%285db1vcue 5xygg1 rvhryhbyzo\%29\%29/Reader.aspx?p=471982\&o=1338\&u=ncx2BZEm VtA\%3d\&t=1453963667\&h=A2023D204AB4F62A0D5444D66280696B067 6 A615\&s $=41603136 \& u t=4509 \& p g=1 \& r=i m g \& c=416 \& p a t=n \& c m s=2 \& s d=2 \#$

Brennan, E.M. \& Brennan, J.S. (1981). Accent scaling and language attitudes: reactions to Mexican American English speech. Language and Speech, 24(3), 207-221. Retrieved from http://web.a.ebscohost.com.proxy.lib.pdx.edu /ehost/detail/detail?vid=2\&sid=ea4962a1-9977-4c0a-ad41b98b6560c4ad\%40sessionmgr4010\&bdata=JnNpdGU9ZWhvc3QtbGl2ZQ\%3 $\mathrm{d} \% 3 \mathrm{~d} \# \mathrm{AN}=14091466 \& \mathrm{db}=\mathrm{aph}$

Brizuela, M., Andersen, E., \& Stallings, L. (1999). Discourse markers as indicators of register. Hispania, 82(1), 128-141. Retrieved from http://www.jstor.org/ stable/346098?origin=JSTOR-pdf\&seq=1\#page_scan_tab_contents

Carpenter, J. \& Hilliard, S. (2005). Shifting parameters of individual and group variation: African American English on Roanoke Island. Journal of English Linguistics 33(161), 161-184. doi: 10.1177/0075424205278952

Castaneda, L. (2017, September 10). Spanish fluency in the U.S. decreases with each 
generation. USA Today. Retrieved from https://www.usatoday.com

Caufield, J. (2015, April 23). Audience boos when protester disrupts Perry kindergarten concert with 'English only' chant. The Perry News. Retrieved from http://theperrynews.com/audience-boos-when-protester-disruptsperry-kindergarten-concert-with-english-only-chant/

Chan, Y. C. (2010). Should English slang be taught to ESOL students? TESOL Journal, 1(4), 520-521. doi: 10.5054/tj2010.240317

Charkova, K. (2007) A language without borders: English slang and Bulgarian learners of English. Language Learning, 57(3), 369-416. Retrieved from http://web.a.ebscohost.com.proxy.lib.pdx.edu/ehost/pdfviewer/pdfviewer? sid=035fe796-383f-4531-8fc8-7454d02bcae8\%40sessionmgr4001\&vid= 1 \&hid $=4107$

Deci, E.L. \& Ryan, R. M. (2000). The "what" and "why" of goal pursuits: Human needs and the self-determination of behavior. Psychological Inquiry, 11(4), 227268. Retrieved from http://www.jstor.org/stable/1449618

Demographic profile of Hispanics in California, 2014. (2017). Pew Research Center: Hispanic Trends. Retrieved from http://www.pewhispanic.org/states/state/ca/

Demographic profile of Hispanics in Oregon, 2014. (2017). Pew Research Center: Hispanic Trends. Retrieved from http://www.pewhispanic.org/states/state/or/

DeVoe, P. (2017, September 1). No, insisting on proper English grammar and 
spelling is not 'elitist.' National Review. Retrieved from http://www.nationalreview.com

Dewaele, J.M. \& McCloskey, J. (2013). Attitudes toward foreign accents among adult multilingual language users. Journal of Multilingual and Multicultural Development, 36(3), 221-238. Retrieved from http://dx.doi.org.proxy.lib.pdx.edu/10.1080/01434632.2014.909445

Dörnyei, Z. (2009). The L2 motivational self system. In: Z. Dörnyei, \& E. Ushioda (Eds.), Motivation, language identity and the L2 self (pp. 9-42). New York: Multilingual Matters.

Dowling, J.A., Ellison, C.G., \& Leal, D.L. (2012). Who doesn't value English? Debunking myths about Mexican immigrants' attitudes toward the English language. Social Science Quarterly, 93(2), 356-378. doi: 10.1111/j.15406237.2012.00850.x

Encuesta: ¿Qué opinas del Spanglish? [Poll: What do you think about Spanglish?] (2010, November 11). Saberhispano.com. Retrieved from http://www.saberhispano.com/mundolatino/encuesta-spanglish/

Fought, C. (2005). Talking with mi gente: The distinctive dialect of Chicano English. PBS. Retrieved from http://pbs.org/speak/seatosea/american varieties/chicano/

Fuhrmann, H. (2011 July). Usage: 'Latino' preferred over 'Hispanic.' Los Angeles Times. Retrieved from http://latimesblogs.latimes.com/readers/2011/07/ latino-preferred-over-hispanic-in-most-cases.html

Galetcaia, T. (2014). The many faces of the language ego: Exploring tensions of 
linguistic and cultural adaptation in immigrants and adult language learners. Procedia: Social and Behavioral Sciences, 116(2), 4270-4276. Retrieved from https://www-sciencedirect-com.proxy.lib.pdx.edu/science/article /pii/S1877042814009471

Gallois, C. \& Callan, V. (1991). Interethnic accommodation: the role of norms. In H. Giles, J. Coupland, \& N. Coupland (Eds.), Contexts of accommodation: Developments in applied linguistics (pp 245-269). New York: Cambridge University Press.

Gardner, R.C. (1968). Attitudes and motivation: Their role in second-language acquisition. TESOL Quarterly, 2(3), 141-150. Retrieved from http://www.jstor.org/stable/3585571

Gardner, R.C. (2001). Language learning motivation: The student, the teacher, and the researcher. Texas Papers in Foreign Language Education, 6(1), 1-20. Retrieved from http://files.eric.ed.gov/fulltext/ED464495.pdf

Gardner, R.C. (2010). Motivation and second language acquisition. New York: Peter Lang Publishing, Inc.

Gatbonton, E., Trofimovich, P., \& Segalowitz, N. (2011). Ethnic group affiliation and patterns of development of a phonological variable. The Modern Language Journal, 95(2), 188-204. doi: 10.1111/j.1540-4781.2011.01177.x

Giles, H., Coupland, N., \& Coupland, J. (1991). Accommodation theory: Communication, context, and consequence. In: H. Giles, J. Coupland, \& N. Coupland (Eds.), Contexts of Accommodation: Developments in applied linguistics (pp. 1-68). New York: Cambridge University Press. 
Guskin, E. \& Mitchell, A. (2016). Hispanic media: Faring better than the mainstream media. The state of the news media 2011. Retrieved from http:// www.stateofthemedia.org/2011/hispanic-media-fairing-better-than-themainstream-media/

Harper, C. \& de Jong, E. (2004). Misconceptions about teaching English-language learners. Journal of Adolescent and Adult Literacy, 48(2), 152-162. doi: 10.1598/JAAL.48.2.6

Haukås, Å. (2016). Teacher's beliefs about multilingualism and a multilingual pedagogical approach. International Journal of Multilingualism, 13(1), 1-18. doi: $10.1080 / 14790718.2015 .1041960$

Helfrich, H. (1979). Age markers in speech. In K. R. Scherer \& H. Giles (Eds.), Social markers in speech (pp. 63-107). Great Britain: Cambridge University Press.

Hempstead students say principal tried to ban them from speaking Spanish (2013, December 2). Khou.com. Retrieved from http://www.khou.com/story/ news/local/2014/07/24/12269076/

Hernandez, S. \& Reinstein, J. (2017, May 21). A man went on a racist tirade because a guy talked to his Puerto Rican mom in Spanish. [Web log post]. Retrieved from https://www.buzzfeed.com/salvadorhernandez/a-manwent-off-on-a-racist-tirade-because-a-guy-talkedto?utm_term=.sbmY8zGJ6\#.cy1MnXOaE

Huang, J. (2013, November 4). English language learners demand slang; teachers try 
to keep up [Web log post]. Retrieved from: http://www.scpr.org/blogs/ multiamerican/2013/11/04/15109/english-language-learners-demandslang-teachers-tr/

Immigration Policy Center (2010, May 14). New Americans in the Beaver State: The political and economic power of immigrants, Latinos, and Asians in Oregon. American Immigration Council. Retrieved from http://www.oregon.gov/ Hispanic/pdfs/new_americans_in_the_beaver_state_2010.pdf

Kerevel, Y.P. (2011). The influence of Spanish-language media on Latino public opinion and group consciousness. Social Science Quarterly, 92(2), 509534. doi:10.1111/j.1540-6237.2011.00780.x

Kim, T.Y. (2011). Sociocultural dynamics of ESL learning (de)motivation: An activity theory analysis of two adult Korean immigrants. The Canadian Modern Language Review, 67(1), 91-122. Retrieved from http:// ejournals.ebsco.com.proxy.lib.pdx.edu/Direct.asp?AccessToken=6VLXFLH89 XIVFXF3FKMFCJO32XJM8L2XVK\&Show=0bject\&msid=-419381942

Klemack, J.C. \& Lloyd, J. (2015). Caught on camera: Woman berates IHOP customer for speaking Spanish. NBC4 News. Retrieved from http://www.nbclosangeles.com/news/local/IHOP-English-Spanish-Rant320609602.html

Labov, W. (2001). Principles of linguistic change: Social factors. Massachusetts: Blackwell Publishers, Inc. Lasagabaster, D. (2017). Language learning motivation and language attitudes in 
multilingual Spain from an international perspective. The Modern Language Journal, 101(3), 583-596. doi: 10.1111/modl.12414

Laver, P. \& Trudgill, P. (1979). Phonetic and linguistic markers in speech. In K. R. Scherer \& H. Giles (Eds.), Social markers in speech (pp. 1-32). Great Britain: Cambridge University Press.

Lipski, J. (2000). The linguistic situation of Central Americans. In S.C. Wong \& S. McKay (Eds.), New immigrants in the United States (pp. 189-215). United Kingdom: Cambridge University Press.

Liu, A.H. \& Sokhey, A.E. (2014, June 18). When and why do U.S. states make English their official language? The Washington Post. Retrieved from https://www.washingtonpost.com

Mason Carris, L. (2011). La voz gringa: Latino stylization of linguistic (in)authenticity as social critique. Discourse and Society, 22(474), 474-490. doi: $10.1177 / 0957926510395835$

Matsa, K.E. (2015). Hispanic media: Fact sheet. Pew Research Center Journalism \& Media. Retrieved from http://www.journalism.org/2015/04/29/hispanicmedia-fact-sheet/

McKay, S. \& Wong, S.C. (2000). Introduction. In S.C. Wong \& S. McKay (Eds.), New immigrants in the United States (pp. 1-7) United Kingdom: Cambridge University Press.

Mendoza, M. (2009, September 15). 150 years of Latino contributions in Oregon. Retrieved from http://www.oregon.gov/Hispanic/pdfs/ 150_Years_of_Latino_Contributions_in_Oregon.pdf 
Mori, M. (2014). Conflicting ideologies and language policy in adult ESL:

Complexities of language socialization in a majority-L1 classroom. Journal of Language, Identity, and Education, 13, 153-170. doi:

$10.1080 / 1534858.2014 .919810$

MuCulloch, G. (2014, May 30). Why do you think you're right about language? You're not. [Web log post]. Retrieved from http://www.slate.com/blogs/ lexicon_valley/2014/05/30/arguing_over_language_everyone_has_an_idiolec t_standard_english_prescriptivism.html

Multnomah County, Oregon. (2017). Pew Research Center: Hispanic Trends. Retrieved from http://www.pewhispanic.org/states/county/41051/

Norton, B. \& Toohey, K. (2011). Identity, language learning, and social change. Language Teaching, 44(4), 412-446. doi: 10.1017/S0261444811000309

Norton Peirce, B. (1995). Social identity, investment, and language learning. TESOL Quarterly, 29(1), 9-31. Retrieved from http://www.jstor.org/stable/ 3587803

Nye, T. (2013, October 27). Janesville man arrested on tentative battery charge with hate crime enhancer after allegedly punching Hebrew speakers. Madison.com. Retrieved from http://host.madison.com/news/local/ crime_and_courts/janesville-man-charged-with-hate-crime-after-punchinghebrew-speakers/article_a6bee93a-3f02-11e3-b9d7-001a4bcf887a.html

O'Grady, W., Archibald, J., Aronoff, M., \& Rees-Miller, J. (2010). Contemporary linguistics: An introduction. Massachusetts: Bedford/St. Martin's. Ortega, L.B. (2008). Attrition of ESL foreign-born Hispanic students at CSN (Master's 
thesis). Available from Proquest Dissertations and Theses database. (UMI No. 1456362)

Ortiz, K. (2017, October 13). Cliffside Park High School teacher tells student to 'Speak American.' North Jersey. Retrieved from http://www.northjersey.com

Otheguy, R. \& Stern, N. (2011). On so-called Spanglish. International Journal of Bilingualism 15(1), 85-100. Retrieved from http://dx.doi.org.proxy.lib.pdx.edu/10.1177 /1367006910379298

Paquet-Gauthier, M. \& Beaulieu, S. (2016). Can language classrooms take the multilingual turn? Journal of Multilingual and Multicultural Development, 37(2), 167-138. doi: 10.1080/1434632.2015.1049180.

Penfield, J. \& Ornstein-Garcia, J. (1985). Chicano English: An ethnic contact dialect [Academic Complete version]. doi: 10.1075/veaw.g7

Perry, F.L. (2005). Understanding data gathering. Research in applied linguistics: Becoming a discerning consumer. New Jersey: Lawrence Erlbaum Associates, Inc.

Retta, E. \& Brink, C. (2007). Latino or Hispanic panic: Which term should we use? Crossculturecommunications.com. Retrieved from www.crossculturecommunications.com/latino-hispanic.pdf

Rickford, J.R. \& Eckert, P. (2002). Introduction. In Rickford, J.R. \& Eckert, P. (Eds.), Style and sociolinguistic variation, (pp. 1-18) [Proquest Ebrary version]. Retrieved from http://site.ebrary.com/lib/portlandstate/ reader.action?docID=10073580\# 
Rickford, J.R. \& McNair-Knox, F. (1994). Addressee- and topic-influenced style shift: A quantitative sociolinguistic study. In Biber, D. \& Finegan, E. (Eds.), Sociolinguistic perspectives on register, (pp. 235-276) [Proquest Ebrary version]. Retrieved from http://site.ebrary.com/lib/portlandstate/ reader.action?docID=10087524\&ppg=10

Risager, K. (2007). Cultural pedagogy today-questioning of the national paradigm. In Language and culture pedagogy: from a national to a transnational paradigm (pp. 141-165) [ProQuest Ebook Central version]. Retrieved from https://ebookcentral-proquest-com.proxy.lib.pdx.edu/lib/psu/ reader.action?docID=293218\&ppg=153

Rockow, J. (2014, December 21). Oregon Latino identity, explored. The Bulletin. Retrieved from http://bendbulletin.com

Romero, S. (2017, August 23). Spanish thrives in the U.S. despite an Englishonly drive. The New York Times. Retrieved from https://www.nytimes.com Ryan, C. (2013). Language use in the United States: 2011. American community survey reports. United States Census Bureau. Retrieved from: https://www.census.gov/prod/2013pubs/acs-22.pdf

Ryder, A., Alden, L.E., \& Paulhus, D.L. (2000). Is acculturation unidimensional or bidimensional? A head-to-head comparison in the prediction of personality, self-identity, and adjustment. Journal of Personality and Social Psychology, 79(1), 49-65. doi: 10.1037/0022-3514.79.1.49

Shankar, S. (2005). Speaking like a model minority: "FOB" styles, gender, and racial 
meanings among Desi teens in Silicon Valley. Journal of Linguistic Anthropology, 18(2), 268-289. Doi: 10.1111/j.1548-1395.2008.00022.x

Smith, P. M. (1979). Sex markers in speech. In Scherer, K. R. \& Giles, H. (eds) (1979). Social markers in speech. Great Britain: Cambride University Press. (pp. 109-146).

Stavans, I. (2017, July 20.) For the love of Spanglish. The New York Times. Retrieved from https://www.nytimes.com

Taylor, P., Lopez, M.H., Martínez, J., \& Velasco, G. (2012). When labels don't fit: Hispanics and their views of identity. Pew Research Center: Hispanic Trends. Retrieved from http://www.pewhispanic.org/2012/04/04/when-labelsdont-fit-hispanics-and-their-views-of-identity/

United States Census Bureau. [ca. 2010] The foreign-born population in the United States. [Slideshow presentation]. Retrieved from https://www.census.gov/newsroom/pdf/cspan_fb_slides.pdf

Ushioda, E. (2009). A person-in-context relational view of emergent motivation, self, and identity. In: Z. Dörnyei \& E. Ushioda (Eds.) Motivation, language identity and the L2 self (pp. 215-228). New York: Multilingual Matters. Washington County, Oregon. (2017). Pew Research Center: Hispanic Trends. Retrieved from http://www.pewhispanic.org/states/county/41067/ Zea, M.C., Asner-Self, K.K., Birman, D., \& Buki, L.P. (2003). The abbreviated multidimensional acculturation scale: Empirical validation with two Latino/Latina samples. Cultural Diversity and Ethnic Minority Psychology, 9(2), 107-126. doi: 10.1037/1099-9809.2.107 
Zuengler, J. (1991). Accommodation in native-nonnative interactions: Going beyond the "what" to the "why" in second-language research. In H. Giles, J. Coupland \& N. Coupland (Eds.), Contexts of accommodation: Developments in applied linguistics (pp. 223-244). New York: Cambridge University Press. 
Appendix A

English-Language Survey

---General Information---

1) Country of origin:

2) Age:

3) Gender:

4) Are you a U.S. Citizen? $\square$ Yes $\square$ No $\square$ Prefer not to answer

$\begin{array}{llll}\text { 5) Time in the } & \square \text { Less than 1 year } & \square \text { 1-3 years } & \square \text { 3-5 years } \\ \text { U.S.A.: } & \square \text { 5-7 years } & \square \text { 7-10 years } & \square \text { More than } 10 \\ & & \end{array}$

6) Level of

English:

Beginning

Intermediate

Advanced

\section{7) Linguistic Identity (Please mark all that apply):}

\begin{tabular}{|c|c|c|c|}
\hline $\begin{array}{r}\square \text { Spanish- } \\
\text { speaker }\end{array}$ & $\square$ Spanish student & $\square$ Bilingual & $\square$ I don't know \\
\hline $\begin{array}{l}\square \text { English- } \\
\text { speaker }\end{array}$ & $\square$ English student & $\square$ Multilingual & $\begin{array}{l}\square \text { Prefer not to } \\
\text { answer }\end{array}$ \\
\hline
\end{tabular}


Section A.

\section{1) Why are you learning English? Please mark all that apply.}

To find work

To learn U.S. culture

To make new friends

To improve basic skills/ continue with education
To speak with my family or friends

To speak with people in my community (in church, at work, and/or in my children's school)

$\square$ To become a U.S. citizen

Another reason:

\section{2) Which strategies do you use to learn English? Please mark all that apply.}

Take English classes

Participate in conversation groups

Speak English with my family or friends

Speak English with the people in my community (in church or in my children's school)
Watch TV or movies in English

Read books, newspapers, or magazines in English

Listen to music, the radio, or podcasts in English

Use English on the internet

Other strategies: 
1) Please indicate your agreement with the following sentences by marking the option that best represents your opinion.

\begin{tabular}{|c|c|c|c|c|c|c|}
\hline & $\begin{array}{l}\text { Strongly } \\
\text { Agree }\end{array}$ & Agree & $\begin{array}{l}\text { Neither } \\
\text { agree nor } \\
\text { disagree }\end{array}$ & Disagree & $\begin{array}{l}\text { Strongly } \\
\text { disagree }\end{array}$ & $\begin{array}{l}\text { I don't } \\
\text { know }\end{array}$ \\
\hline $\begin{array}{l}\text { 1. I consider myself a } \\
\text { citizen of the country I } \\
\text { am from. }\end{array}$ & $\square$ & $\square$ & $\square$ & $\square$ & $\square$ & $\square$ \\
\hline $\begin{array}{l}\text { 2. I consider myself a } \\
\text { citizen of the U.S.A. }\end{array}$ & $\square$ & $\square$ & $\square$ & $\square$ & $\square$ & $\square$ \\
\hline
\end{tabular}

\section{I believe that I am part of the culture of my country of origin.}

4. I believe I am part of U.S. American culture.

\section{Being a citizen of my country of origin is very important to me.}

6. Being a citizen of the United States is very important to me.

\section{Maintaining or developing cultural practices from my country of origin is important to me.}

8. Maintaining or developing cultural practices from the United States is important to me.

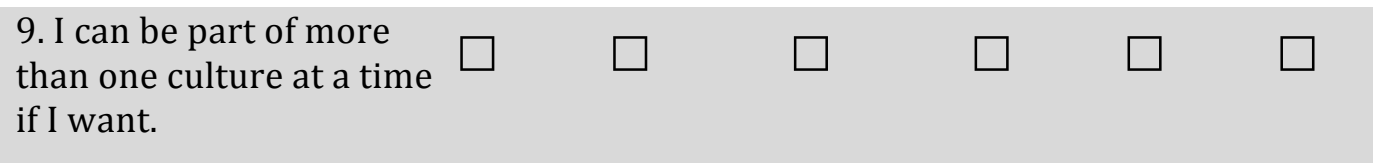

10. I can be part of only one culture at a time. 


\title{
2) Are you interested in learning about or participating in U.S. American culture?
}

\author{
Yes $\square$ No* $\square$ I don't know \\ *If the answer is "no," continue to Section C.
}

3) In your opinion, which strategies would help you learn about or participate in U.S. American culture? Please mark all that apply.

Learning or using English

Learning or using Spanish

Working with people who speak English

Using English in my community (in church, in my school or in my children's school)
Make friends who speak English

Use English on the internet

Watch TV or movies in English

Listen to music, the radio, or podcasts in English

Other strategies:

4) Which strategies do you currently use to learn about or participate in U.S. American culture? Please mark all that apply.

Learning or using English

Learning or using Spanish

Working with people who speak English

Using English in my community (in church, in my school or in my children's school)
Make friends who speak English

Use English on the internet

Watch TV or movies in English

Listen to music, the radio, or podcasts in English

Other strategies: 
Section $C$

1) Please indicate your agreement with the following sentences by marking "always," "sometimes," or “never." If you don't know, mark “I don't know."

1. The English we learn in class in the U.S. is
the same English that my coworkers use.
2. The English we learn in class in the U.S. is
the same English that people on TV use.
3. The English we learn in class in the U.S. is
the same English that people in my school
use.
4. The English we learn in class in the U.S. is
the same English people use on the internet.
5. The English we learn in class in the U.S. is
the same English used in popular music.
6. The English we learn in class in the U.S. is
the same English my friends use.
7. The English we learn in class in the U.S. is
the same English my family uses.

Section $D$

Instructions: Indicate your agreement with the following statements by marking the option that best represents your opinion.

\section{1) It's important to know informal and colloquial forms of English, including} "bad" words.

\begin{tabular}{|c|c|c|c|c|c|}
\hline $\begin{array}{c}\text { Strongly } \\
\text { agree }\end{array}$ & Agree & $\begin{array}{c}\text { Neither } \\
\text { agree nor } \\
\text { disagree }\end{array}$ & Disagree & $\begin{array}{l}\text { Strongly } \\
\text { disagree }\end{array}$ & $\begin{array}{l}\text { I don't } \\
\text { know }\end{array}$ \\
\hline$\square$ & $\square$ & $\square$ & $\square$ & $\square$ & $\square$ \\
\hline
\end{tabular}




\section{2) In your opinion, what strategies would help you learn informal or colloquial types of English, including "bad" words? Please mark all that apply.}

Take English classes

Speak English with my family and friends

Speak English with people in my community (in my job, at church, in my children's school)

Use English on the internet

Participate in English conversation groups
Watch TV or movies in English

Read books, newspapers, or magazines in English

Listen to music, the radio, or podcasts in English

I'm not interested in learning these types of English

Other strategies:

3) What strategies do you currently use to learn informal or colloquial forms of English, including "bad" words? Please mark all that apply.

Take English classes

Speak English with my family and friends

Speak English with people in my community (in my job, at church, in my children's school)

Use English on the internet

Participate in English conversation groups
Watch TV or movies in English

Read books, newspapers, or magazines in English

Listen to music, the radio, or podcasts in English

$\square$ I'm not interested in learning these types of English

Other strategies: 


\section{4) I think that knowing informal or colloquial forms of English, including "bad" words, could help me (please mark all that apply):}

Communicate at work

Communicate with my family and friends

Make new friends or meet new people

Communicate with people in my community (in church, in my school, or in my children's school)

Learn English in class
Understand TV or movies in English

Use English on the internet

Understand music, the radio, or podcasts in English

Understand books, newspapers, or magazines in English

I don't think knowing these types of English will help me with any of these things

Other:

Section E

1) Do you use a mix of English and Spanish or "Spanglish?"

Yes $\square$ No*

*If the answer is "no," continue to Section F.

Instructions: Indicate your agreement with the following statements by marking the option that best represents your opinion.

\section{2) I use a mix of English and Spanish or Spanglish...}

I don't

Always Sometimes Never know

\begin{tabular}{|c|c|c|c|c|}
\hline 1.... at work & $\square$ & $\square$ & $\square$ & $\square$ \\
\hline 2.... at school & $\square$ & $\square$ & $\square$ & $\square$ \\
\hline 3. ... with my friends & $\square$ & $\square$ & $\square$ & $\square$ \\
\hline 4.... with my family & $\square$ & $\square$ & $\square$ & $\square$ \\
\hline $\begin{array}{l}5 . . . \text { in my community (in church, or in } \\
\text { my children's school) }\end{array}$ & $\square$ & $\square$ & $\square$ & $\square$ \\
\hline $6 . .$. on the internet & $\square$ & $\square$ & $\square$ & $\square$ \\
\hline 7. ...in other situations?: & $\square$ & $\square$ & $\square$ & $\square$ \\
\hline
\end{tabular}


Section F.

1) Have you noticed other people among your friends, family, or community using a mix of English and Spanish or "Spanglish"?

* If the answer is "no," continue to Section G.

Instructions: Indicate your agreement with the following statements by marking the option that best represents your opinion.

2) The people I know use a mix of English and Spanish or Spanglish...

$\begin{array}{lcccc} & \text { Always } & \text { Sometimes } & \text { Never } & \text { I don't } \\ \text { know }\end{array}$




\section{1) I think that using a mixture of English and Spanish, or Spanglish, could help} me (please mark all that apply):

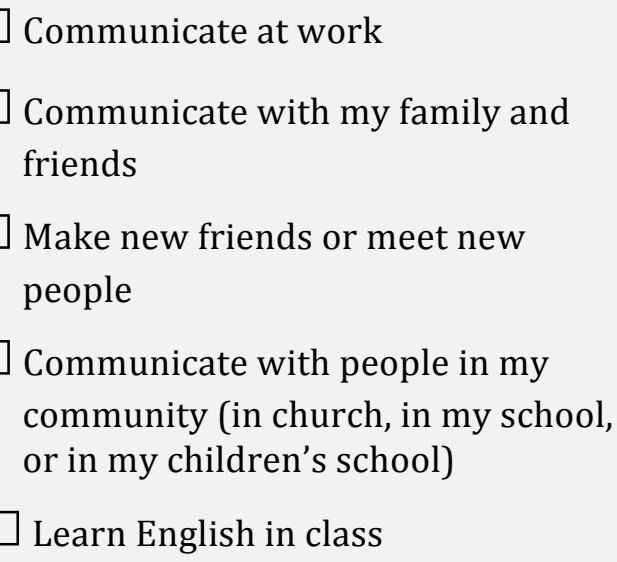

Understand TV or movies in English

Use English on the internet

Understand music, the radio, or podcasts in English

Understand books, newspapers, or magazines in English

I don't think knowing these forms will help me with any of these things

Other:

Section $H$

1) Do you use a type of English that has been influenced by Spanish, like Chicano English, or something similar?

Yes

* If the answer is "no," continue to section I. 
Instructions: Indicate your agreement with the following statements by marking the option that best represents your opinion.

2) I use a type of English like Chicano English or something similar...

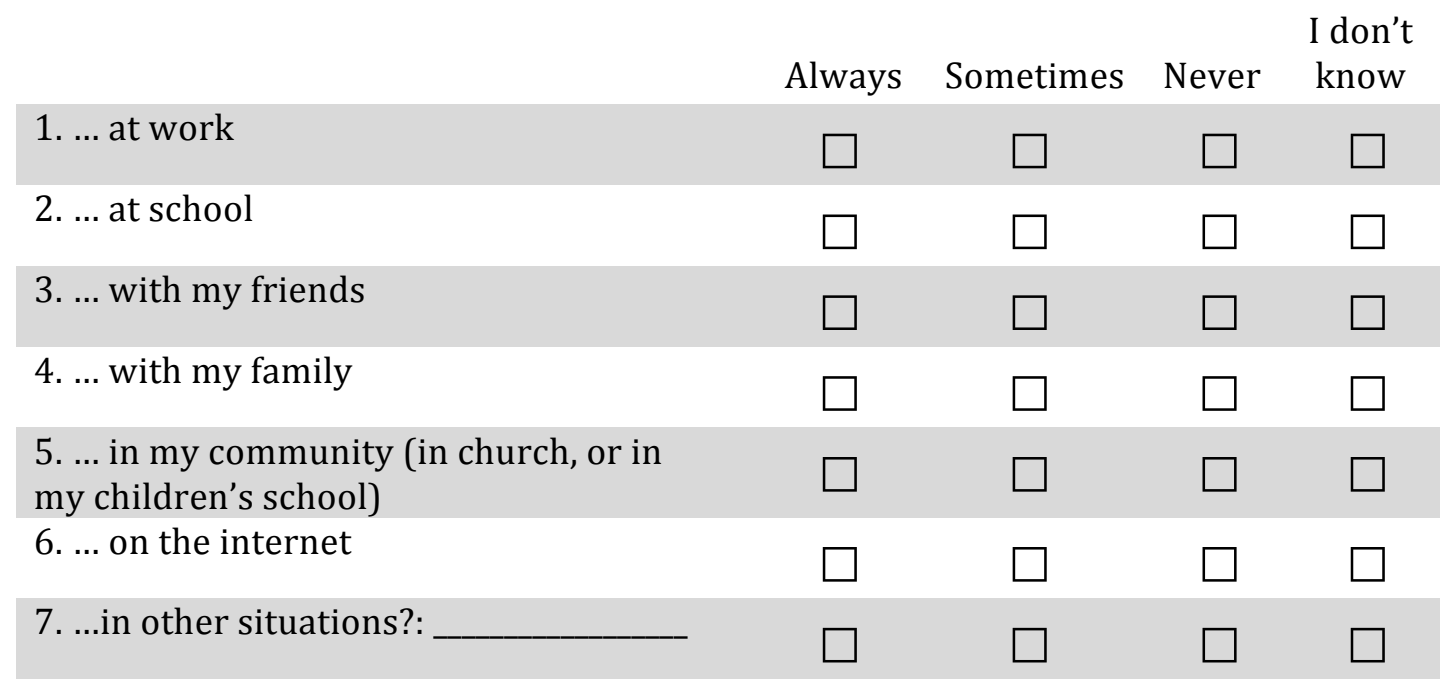

Section 1

1) Have you noticed other people among your friends, family or community using a type of English that has been influenced by Spanish, like Chicano English, or something similar?

$\square$ Yes $\square$ No* $\quad \square$ I don't know
*If the answer is “no," continue to Section J.


Instructions: Indicate your agreement with the following statements by marking the option that best represents your opinion.

\section{2) The people I know use a type of English like Chicano English or something similar...}

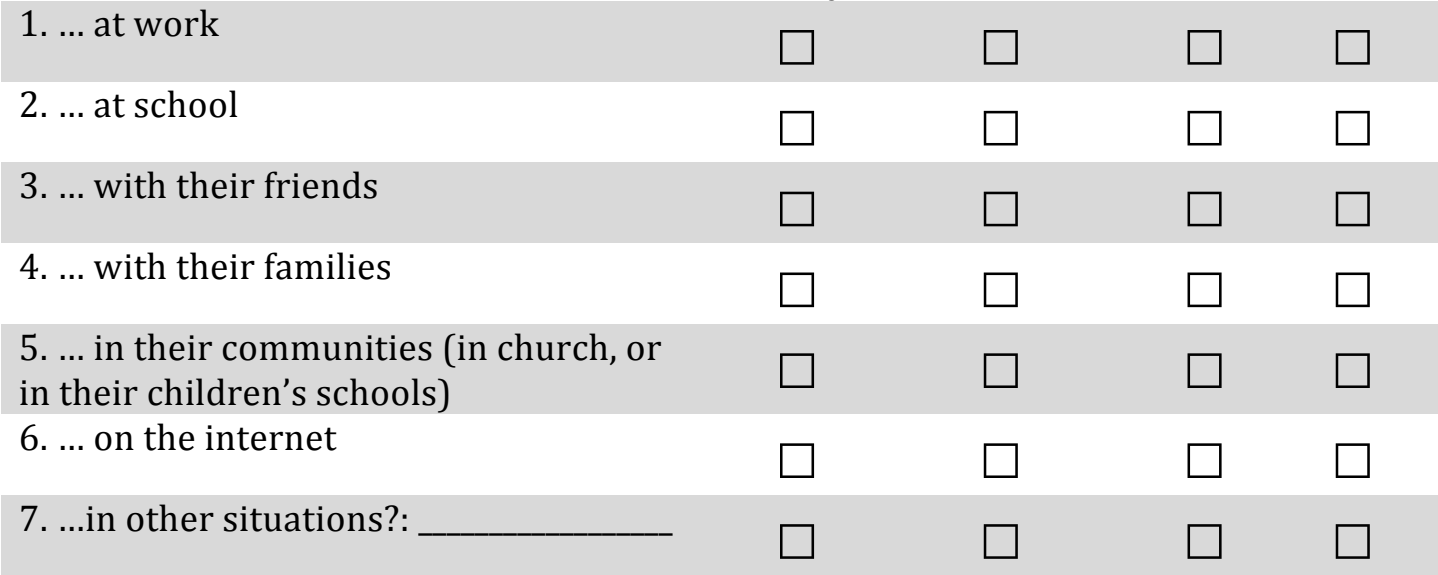

Section J

1) I think that using a type of English like Chicano English could help me (please mark all that apply):

Communicate at work

Communicate with my family and friends

Make new friends or meet new people

Communicate with people in my community (in church, in my school, or in my children's school)

Learn English in class

I don't Always Sometimes Never know 
Appendix B

Spanish Language Survey

---Información General---

1) País de origen:

2) Edad:

3) Género:

4) ¿Es usted ciudadano/a de los E.E.U.U.? $\square$ Sí $\square$ No $\square$ Prefiero no contestar

5) Tiempo en
los E.E.U.U:

$\square$ Menos que 1 año

$\square$ 1-3 años

7-10 años

5-7 años

$\square$ Intermedio

Básico

inglés:

6) Nivel del
Edad: 
Sección A

\section{1) ¿Porqué está usted aprendiendo inglés? Favor de marcar todas las opciones con las cuales esté de acuerdo.}

Conseguir trabajo

Aprender la cultura estadounidense

Hacer nuevos amigos

Mejorar habilidades básicas/ Seguir con la educación $\square$ Hablar con miembros de mi familia o con mis amigos

$\square$ Hablar con la gente en mi comunidad (en la iglesia, en el trabajo, y/o en la escuela de mis hijas/os)

$\square$ Hacerme ciudadana/o de los E.E.U.U.

Otra razón:

\section{2) ¿Cuáles estrategias utiliza usted para aprender el inglés? Favor de marcar} todas las opciones con las cuales esté de acuerdo.

Asistir clases de inglés

Asistir grupos de conversación

Hablar inglés con mi familia o con mis amigos

Hablar inglés con la gente en mi comunidad (en la iglesia y/o en la escuela de mis hijos/as)
Ver películas o la TV en inglés

Leer libros, periódicos, o revistas en inglés

Escuchar música, la radio, o podcasts en inglés

Usar el internet en inglés

Otras estrategias: 
1) Por favor indique su acuerdo con las siguientes declaraciones marcando la opción que mejor represente su opinión.

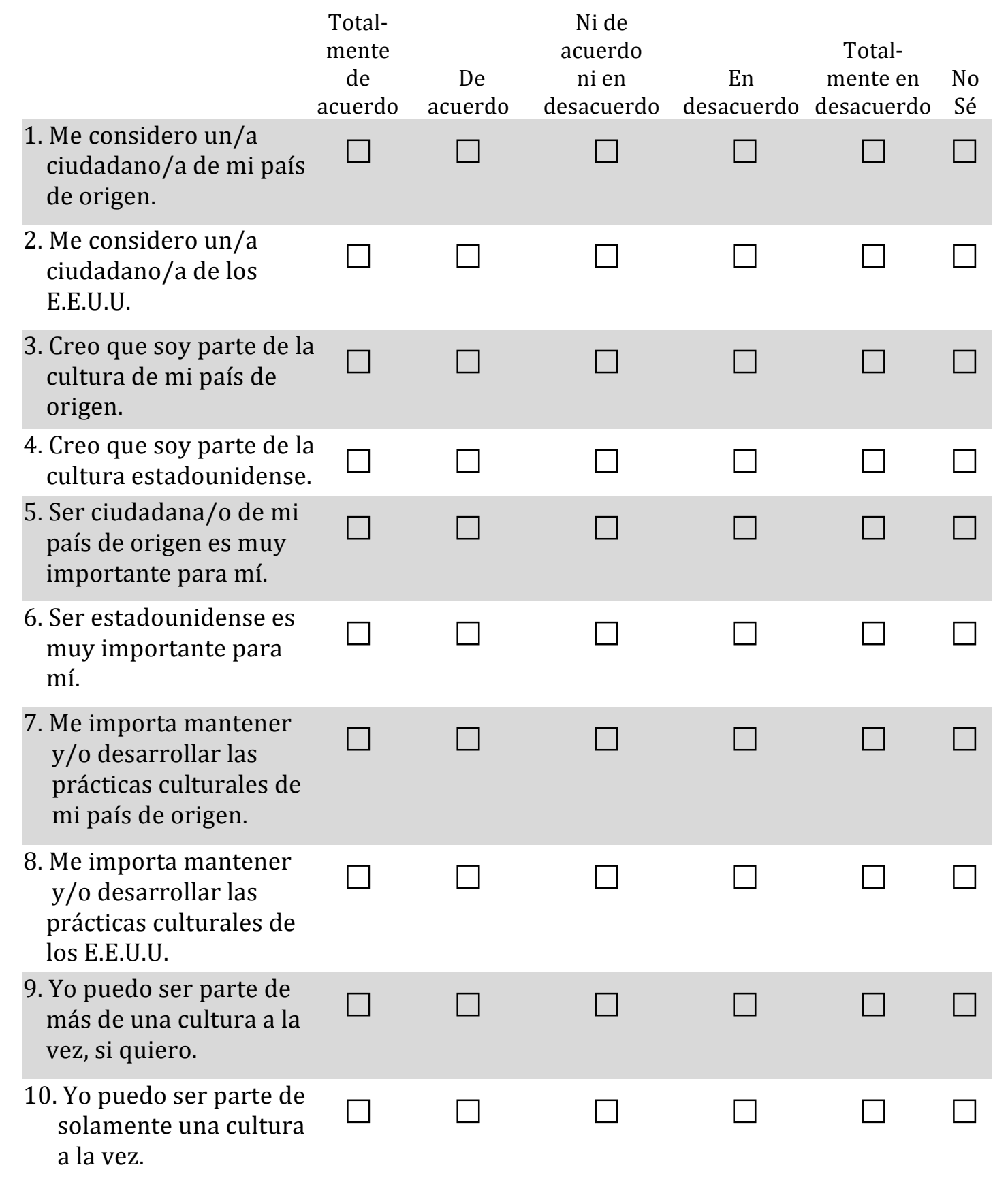




\section{2) $¿ A$ usted le interesa aprender sobre y/o participar en la cultura} estadounidense?
Sí
$\square$ No
No sé
*Si la respuesta es "no," siga a la Sección C

3) En su opinión, ¿cuáles estrategias le ayudarían aprender sobre, o participar en, la cultura estadounidense? Favor de marcar todas las opciones con las cuales esté de acuerdo.

Aprender y/o usar inglés

Aprender o usar español

Trabajar con gente que hablan inglés

Participar en mi comunidad (en la iglesia, en mi escuela o en la escuela de mis hijos/as) en inglés
Hacer amigos que hablan inglés

Usar el internet en inglés

Ver TV o películas en inglés

Escuchar a la música, la radio, o a podcasts en inglés

Otras estrategias:

4) ¿Cuáles estrategias usa usted ahora para aprender sobre, o participar en, la cultura estadounidense? Favor de marcar todas las opciones con las cuales esté de acuerdo.

Aprender o usar inglés

Aprender o usar español

Trabajar con gente que hablé inglés

$\square$ Participar en mi comunidad (en la iglesia, en mi escuela o en la escuela de mis hijos/as) en inglés
Hacer amigos que hablen inglés

Usar el internet en inglés

Ver TV o películas en inglés

Escuchar la música, la radio, o

podcasts en inglés

Otras estrategias: 
Sección $C$

\section{1) Por favor indique su acuerdo con las siguientes declaraciones marcando "siempre," "a veces," o "nunca". Si no sabe, marque "no sé".}
1. El inglés que aprendimos en mis clases en los E.E.U.U. es el mismo inglés que usan mis
Siempre
A veces
Nunca No sé compañeros de trabajo.
2. El inglés que aprendimos en mis clases en los E.E.U.U. es el mismo inglés que usa la gente en la TV.
3. El inglés que aprendimos en mis clases en los E.E.U.U. es el mismo inglés que usa la gente en mi escuela.
4. El inglés que aprendimos en mis clases en los E.E.U.U. es el mismo inglés que usa la gente en el internet.

5. El inglés que aprendimos en mis clases en los E.E.U.U. es el mismo inglés que usa la gente en la música popular.

6. El inglés que aprendimos en mis clases en los E.E.U.U. es el mismo inglés que usan mis amigos.

7. El inglés que aprendimos en mis clases en los E.E.U.U. es el mismo inglés que usan miembros de mi familia.

Sección D

Instrucciones: Indique su acuerdo con las siguientes declaraciones marcando la opción que mejor representé su opinión.

\section{1) Es importante saber el inglés informal y coloquial incluyendo las palabras "malas".}

\begin{tabular}{cccccc} 
& \multicolumn{3}{c}{ Ni de } & & Totalmente \\
acuerdo & ni en & En & en & No \\
Totalmente & De & desacuerdo & desacuerdo & desacuerdo & Sé \\
de acuerdo & acuerdo & desacula & $\square$ & $\square$ & $\square$
\end{tabular}




\section{2) En su opinión, ¿cuales estrategias le ayudarían aprender el inglés informal o coloquial incluyendo las "malas" palabras? Favor de marcar todas las opciones con las cuales esté de acuerdo.}

Asistir las clases de inglés

Hablar con miembros de mi familia o con mis amigos

Hablar con la gente en mi comunidad (en el trabajo, en la iglesia, en la escuela de mis hijos/as)

Usar el internet en inglés

Participar en los grupos de conversación en inglés
Ver películas o la TV en inglés

Leer libros, periódicos, o revistas en inglés

$\square$ Escuchar música, la radio, o podcasts en inglés

No me interesa aprender estas formas del inglés

Otras estrategias:

3) ¿Cuales estrategias usa usted ahora para aprender el inglés informal o coloquial incluyendo las palabras "malas"? Favor de marcar todas las opciones con las cuales esté de acuerdo.

Asistir las clases de inglés

Hablar con miembros de mi familia o con mis amigos en inglés

$\square$ Hablar con la gente en mi comunidad (en el trabajo, en la iglesia, en la escuela de mis hijos/as)

Usar el internet en inglés

Participar en los grupos de conversación en inglés
Ver películas o la TV en inglés

Leer libros, periódicos, o revistas en inglés

Escuchar música, la radio, o podcasts en inglés

$\square$ No me interesa aprender estas formas del inglés

Otras estrategias: 
4) Pienso que saber el inglés que es informal o coloquial incluyendo las palabras "malas" me podría ayudar a (favor de marcar todas las posibilidades con las cuales esté de acuerdo):

$\begin{array}{lc}\square \text { Comunicar en el trabajo } & \square \text { Entender la TV y/o las películas en } \\ \square \text { Comunicar con mi familia y/o con } & \text { inglés } \\ \text { mis amigos } & \square \text { Usar el internet en inglés } \\ \square \text { Hacer nuevos amigos y/o conocer a } & \square \text { Entender la música, la radio, o } \\ \text { nueva gente } & \text { podcasts en ingles } \\ \square \text { Comunicar con la gente en mi } & \square \text { Entender libros, periódicos, y/o } \\ \begin{array}{l}\text { comunidad (en la iglesia, en mi } \\ \text { escuela o en la escuela de mis } \\ \text { hijos/as) }\end{array} & \text { revistas en inglés } \\ \square \text { Estudiar en clases de inglés } & \text { No pienso que saber estas formas } \\ & \text { del inglés me ayudaría en ninguna }\end{array}$

Sección E.

1) ¿Usa usted una mezcla del inglés y el español o el "spanglish"?

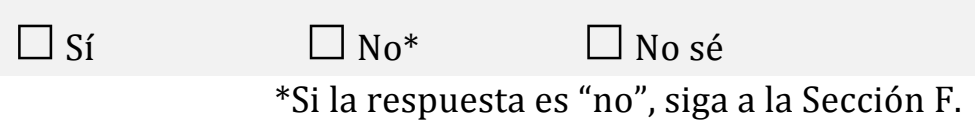

Instrucciones: Indique su acuerdo con las siguientes declaraciones marcando la opción que mejor represente su opinión.

\section{2) Uso una mezcla del inglés y el español o el spanglish....}

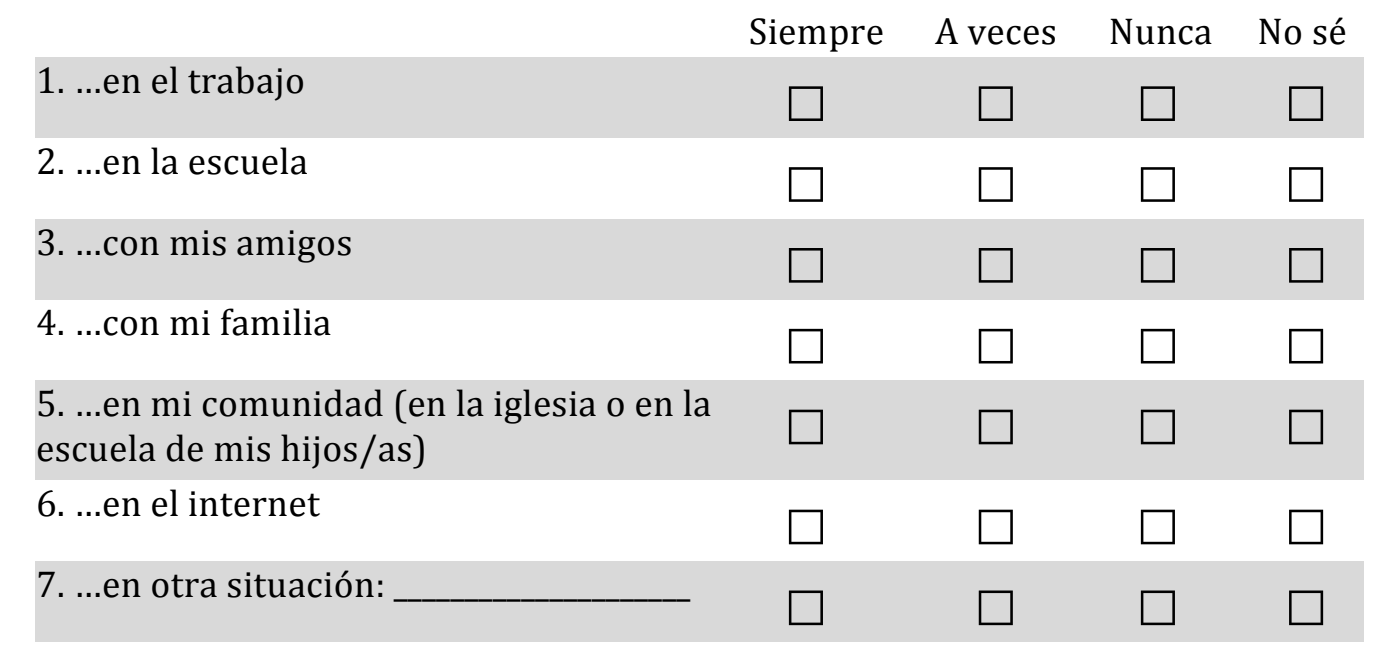


Sección F...

1) ¿Ha notado usted que otras personas entre sus amigos, familia, o comunidad usan una mezcla del inglés y el español, o el "spanglish"?

$\square$ Sí

$\square$ No* $^{*} \square$ No sé

*Si la respuesta es "no", siga a la Sección G.

Instrucciones: Indique su acuerdo con las siguientes declaraciones marcando la opción que mejor represente su opinión.

2) La gente que conozco usan una mezcla del inglés y el español o el spanglish....

\begin{tabular}{|c|c|c|c|c|}
\hline & Siempre & A veces & Nunca & No sé \\
\hline 1....en el trabajo & $\square$ & $\square$ & $\square$ & $\square$ \\
\hline 2. ...en la escuela & $\square$ & $\square$ & $\square$ & $\square$ \\
\hline 3. ...con sus amigos & $\square$ & $\square$ & $\square$ & $\square$ \\
\hline 4....con sus familias & $\square$ & $\square$ & $\square$ & $\square$ \\
\hline $\begin{array}{l}\text { 5. ...en sus comunidades (en sus iglesias } \\
\text { o las escuelas de sus hijos/as) }\end{array}$ & $\square$ & $\square$ & $\square$ & $\square$ \\
\hline 6. ...en el internet & $\square$ & $\square$ & $\square$ & $\square$ \\
\hline 7. ...en otra situación: & $\square$ & $\square$ & $\square$ & $\square$ \\
\hline
\end{tabular}


Sección $G$

1) Pienso que usar una mezcla del inglés y el español, o el spanglish, me podría ayudar a (favor de marcar todas las posibilidades con las cuales esté de acuerdo):

$\begin{array}{lc}\square \text { Comunicar en el trabajo } & \square \text { Entender la TV y/o las películas en } \\ \square \text { Comunicar con mi familia y/o con } & \text { inglés } \\ \text { mis amigos } & \square \text { Usar el internet en inglés } \\ \square \text { Hacer nuevos amigos y/o conocer a } & \square \text { Entender la música, la radio, o } \\ \text { nueva gente } & \text { podcasts en inglés } \\ \square \text { Comunicar con la gente en mi } & \square \text { Entender libros, periódicos, y/o } \\ \text { comunidad (en la iglesia, en mi } & \text { revistas en inglés } \\ \text { escuela o en la escuela de mis } & \square \text { No pienso que usar estas formas } \\ \text { hijos/as) } & \text { me ayudaría en ninguna de estas cosas } \\ \square \text { Estudiar en clases de inglés } & \square \text { Otra cosa: }\end{array}$

Sección $H$

1) ¿Usa usted una forma del inglés que haya sido influenciado por el español, como el inglés chicano, o algo similar?

Sí

$\mathrm{No}^{*}$

No sé

*Si la respuesta es "no", siga a la Sección I.

Instrucciones: Indique su acuerdo con las siguientes declaraciones marcando la opción que mejor represente su opinión.

2) Uso una forma del inglés como el inglés chicano o algo similar:

\begin{tabular}{|c|c|c|c|c|}
\hline & Siempre & A veces & Nunca & No sé \\
\hline 1. ...en el trabajo & $\square$ & $\square$ & $\square$ & $\square$ \\
\hline 2. ...en la escuela & $\square$ & $\square$ & $\square$ & $\square$ \\
\hline 3. ...con mis amigos & $\square$ & $\square$ & $\square$ & $\square$ \\
\hline 4. ...con mi familia & $\square$ & $\square$ & $\square$ & $\square$ \\
\hline $\begin{array}{l}\text { 5. ...en mi comunidad (en la iglesia o la } \\
\text { escuela de mis hijos/as) }\end{array}$ & $\square$ & $\square$ & $\square$ & $\square$ \\
\hline 6. ...en el internet & $\square$ & $\square$ & $\square$ & $\square$ \\
\hline 7. ...en otra situación: & $\square$ & $\square$ & $\square$ & $\square$ \\
\hline
\end{tabular}


Sección I

1) ¿Ha notado usted que otras personas entre sus amigos, familia, o comunidad usan una forma des inglés que haya sido influenciado por el español, como el inglés chicano, o algo similar?
Sí
$\square$ No*
$\square$ No sé
*Si la respuesta es "no", siga la Sección J.

Instrucciones: Indique su acuerdo con la siguiente declaraciones por marcar la opción que mejor representa su opinión.

2) La gente que conozco usa una forma del inglés como el inglés chicano o algo similar...

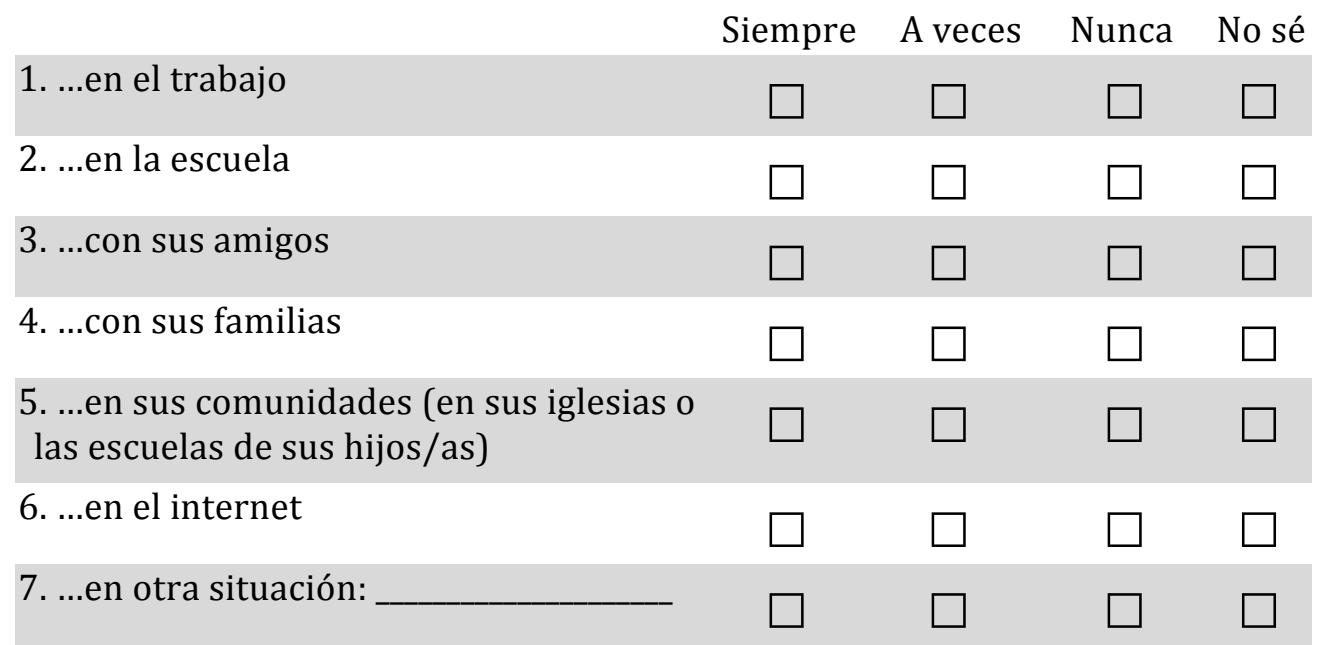




\section{1) Pienso que usar una forma del inglés como el inglés chicano me podría ayudar a (favor de marcar todas las posibilidades con las cuales esté de acuerdo):}

$\square$ Comunicar en el trabajo
$\square$ Comunicar con mi familia y/o con
mis amigos
$\square$ Hacer nuevos amigos y/o conocer a
nueva gente
$\square$ Comunicar con la gente en mi
comunidad (en la iglesia, en mi
escuela o en la escuela de mis
hijos/as)
$\square$ Estudiar en clases de inglés

$\square$ Entender la TV y/o las películas en
inglés
$\square$ Usar el internet en inglés
$\square$ Entender la música, la radio, o
podcasts en inglés
$\square$ Entender libros, periódicos, y/o
revistas en inglés
$\square$ No pienso que usar estas formas
me ayudaría en ninguna de estas cosas
$\square$ Otra cosa:

\section{¡Muchas gracias por su ayuda!}




\section{Appendix C \\ English Language Consent Letter}

Portland State University

Consent to participate in a research study

Title of study: Cultural and Linguistic Identity and the Value of Non-Classroom English

With this letter, you are invited to participate in a research study about the opinions and beliefs of Spanish-speaking English students on language and culture. This investigation is part of a final project of a Master's program at Portland State University (PSU). The study is directed by Cailey Moe (student researcher) and Professor John Hellermann (faculty professor) of the PSU Applied Linguistics department.

Participation in this study consists of completing a questionnaire and sending it by mail in the envelope provided by the researchers. It takes approximately 35 minutes to complete the questionnaire.

There are no known risks to participating in this study. There are no costs to you for participating in this study. The study is designed to benefit society by obtaining new knowledge. It's possible that you will not benefit directly for participating in this study, however, in appreciation of your time, you will be entered in a drawing for a \$25 Visa gift card. To enter, give your contact information to the student investigator, Cailey Moe. This information will not be connected to the questionnaires in any way. The winner of the gift card will be responsible for any taxes that may apply.

Your answers will be anonymous. Participants will not be identified in reports or publications about this study or any other.

Participation in this study is voluntary. You may decline to participate, decline to answer any question, or revoke your consent to participate in the study, for whatever reason, without negative consequences. By completing the questionnaire and mailing it to the student investigator, you give your consent to participate in the study.

If you have questions about the study, you can contact the student investigator Cailey Moe (cailem@pdx.edu / 1-541-270-5828; she speaks Spanish), or Professor John Hellermann (jkh@pdx.edu / 1.503.725.8732).

The Internal Review Board (IRB) of PSU has reviewed this project. If you have questions or concerns about your rights as a research subject, you can contact the PSU Office of Research Integrity at 1-503-725-2227 or by email at hsrrc@pdx.edu. 


\section{Appendix D \\ Spanish Language Consent Letter}

Universidad de Portland State

Consentimento para participar en un estudio de investigación

Título del estudio: La identidad cultural y lingüística y el valor del inglés que se usa afuera de la escuela

Por la mediante carta le solicita que participe en un estudio de investigación sobre las opiniones y creencias sobre el lenguaje y la cultura de estudiantes hispanohablantes que están aprendiendo inglés. Esta investigación es parte del proyecto final de un programa de maestría en la Universidad de Portland State (PSU por sus siglas en inglés). El estudio está dirigido por Cailey Moe (estudiante de investigación) y el profesor John Hellermann del departamento de lingüística aplicada.

Participar en este estudio consiste en contestar un cuestionario y enviarlo por correo en el sobre proporcionado por los investigadores. Completar el cuestionario dura aproximadamente 35 minutos.

No habrá riesgos conocidos si participa en el estudio. No existirá ningún costo por participar en el estudio. La investigación está diseñada para beneficiar a la sociedad mediante la obtención de nuevos conocimientos. Es posible que no reciba ningún beneficio directo por participar en este estudio, sin embargo, en agradecimiento por su tiempo, usted ingresará en un sorteo para ganar una tarjeta de regalo de Visa de \$25. Para participar, puede dar sus datos de contacto a la investigadora, Cailey Moe. Esta información no será conectada de ninguna manera a las respuestas de los cuestionarios. El/La ganador/a de la tarjeta de regalo será responsable de los impuestos asociados.

Sus respuestas serán anónimas. Los participantes no serán identificados en informes o publicaciones sobre este estudio o ningún otro.

La participación en este estudio es voluntaria. Puede negarse a participar, negarse a contestar cualquiera pregunta en concreto, o puede retirar su consentimiento para participar en el estudio, por cualquier motivo, sin sufrir sanciones. Al completar el cuestionario y enviarlo a la investigadora por correo, usted da su consentimiento para participar en la investigación.

Si tiene preguntas sobre el estudio, puede ponerse en contacto con la investigadora Cailey Moe (cailem@pdx.edu / 1.541.270.5828; habla español) o el profesor universitario John Hellermann (jkh@pdx.edu / 1.503.725.8732).

El Comité de Revisión Institucional (IRB por sus siglas en inglés) de la PSU ha revisado este proyecto. Si tiene preguntas o inquietudes acerca de sus derechos como sujeto de una investigación, puede ponerse en contacto con la oficina de la integridad de la investigación de la PSU por teléfono en el 1.503.725.2227 o por correo electrónico hsrrc@pdx.edu. 